\title{
The fate of riverine nutrients on Arctic shelves
}

\author{
V. Le Fouest ${ }^{1}$, M. Babin ${ }^{2}$, and J.-É. Tremblay ${ }^{2}$ \\ ${ }^{1}$ Laboratoire d'Océanographie de Villefranche, BP 8, UMR7093, CNRS \& Univ. Pierre et Marie Curie (Paris VI), 06238 \\ Villefranche-sur-Mer Cedex, France \\ ${ }^{2}$ Takuvik Joint International Laboratory, Université Laval (Canada) \& Centre National de la Recherche Scientifique (France), \\ Département de Biologie, 1045, Avenue de la Médecine, Québec (Québec), G1V 0A6, Canada
}

Correspondence to: V. Le Fouest (lefouest@obs-vlfr.fr)

Received: 2 August 2012 - Published in Biogeosciences Discuss.: 2 October 2012

Revised: 19 February 2013 - Accepted: 7 May 2013 - Published: 4 June 2013

\begin{abstract}
Present and future levels of primary production (PP) in the Arctic Ocean (AO) depend on nutrient inputs to the photic zone via vertical mixing, upwelling and external sources. In this regard, the importance of horizontal river supply relative to oceanic processes is poorly constrained at the pan-Arctic scale. We compiled extensive historical (1954-2012) data on discharge and nutrient concentrations to estimate fluxes of nitrate, soluble reactive phosphate (SRP), silicate, dissolved organic carbon (DOC), dissolved organic nitrogen (DON), particulate organic nitrogen (PON) and particulate organic carbon (POC) from 9 large Arctic rivers and assess their potential impact on the biogeochemistry of shelf waters. Several key points can be emphasized from this analysis. The contribution of riverine nitrate to new $\mathrm{PP}\left(\mathrm{PP}_{\text {new }}\right)$ is very small at the regional scale $(<1 \%$ to $6.7 \%)$ and negligible at the pan-Arctic scale $(<0.83 \%)$, in agreement with recent studies. By consuming all this nitrate, oceanic phytoplankton would be able to use only $14.3 \%$ and $8.7-24.5 \%$ of the river supply of silicate at the panArctic and regional scales, respectively. Corresponding figures for SRP are $28.9 \%$ and $18.6-46 \%$. On the Beaufort and Bering shelves, riverine SRP cannot fulfil phytoplankton requirements. On a seasonal basis, the removal of riverine nitrate, silicate and SRP would be the highest in spring and not in summer when AO shelf waters are nitrogen-limited. Riverine DON is potentially an important nitrogen source for the planktonic ecosystem in summer, when ammonium supplied through the photoammonification of refractory DON $\left(3.9 \times 10^{9} \mathrm{~mol} \mathrm{~N}\right)$ may exceed the combined riverine supply of nitrate and ammonium $\left(3.4 \times 10^{9} \mathrm{molN}\right)$. Nevertheless, overall nitrogen limitation of $\mathrm{AO}$ phytoplankton is expected to persist even when projected increases of riverine DON
\end{abstract}

and nitrate supply are taken into account. This analysis underscores the need to better contrast oceanic nutrient supply processes with the composition and fate of changing riverine nutrient deliveries in future scenarios of plankton community structure, function and production in the coastal AO.

\section{Introduction}

Fifty years ago, the Arctic Ocean (AO) was perceived as a small contributor to the global carbon cycle because of its extensive sea-ice cover and the relatively low light levels experienced by phytoplankton (English, 1961). The AO is now thought to contribute ca. $14 \%$ of the global uptake of atmospheric carbon dioxide (Bates and Mathis, 2009) and, as such, is an important actor in the global carbon cycle. As a consequence of warming, the $\mathrm{AO}$ tends to switch towards a more sub-Arctic state. The earlier and longer exposure of surface waters to sunlight triggers earlier vernal blooms in some parts of the Arctic Ocean (Kahru et al., 2011). Also, it has been suggested based on ocean colour remote sensing data that annual primary production (PP) is increasing (Arrigo et al., 2008). However, recent observations show that the density stratification (i.e. pycnocline) is persistent throughout the year (Tremblay et al., 2008) and strengthening as a result of increasing river discharge (Li et al., 2009). These conditions limit the vertical supply of nutrients offshore and favour small phytoplankton cells at the expense of large ones (Li et al., 2009).

Present and future trends in Arctic PP will depend on nutrient inputs into the photic zone, driven either by ocean mixing, upwelling or external sources 
(Tremblay and Gagnon, 2009). Mixing and upwelling replenish the photic zone with new nutrients transported upwards from below the pycnocline. These nutrients originate mostly from the local remineralization of settling organic matter and from the inflow of Atlantic and Pacific waters. Upward supply can result from tidal or wind-driven erosions of the pycnocline (Wassmann et al., 2006; Hannah et al., 2009; Le Fouest et al., 2011), upwelling when wind blows in a suitable direction along the shelf break (Tremblay et al., 2011) or the ice edge (Mundy et al., 2009) and eddy pumping in shallow anticyclonic eddies (Timmermans et al., 2008). The contribution of these oceanic processes relative to horizontal nutrient supply from rivers and adjacent seas to the Arctic PP regime is poorly constrained at the pan-Arctic scale (Tremblay and Gagnon, 2009).

Continental rivers surrounding the $\mathrm{AO}$ are a potentially significant source of nutrients for circum-Arctic shelf seas. Arctic river discharge is high, representing $10 \%$ of the global freshwater discharge pouring into only $1 \%$ of the global ocean volume (Opshal et al., 1999). While the estimated input of allochthonous inorganic and organic compounds by rivers into the Arctic Ocean is not negligible (Holmes et al., 2000; Dittmar and Kattner, 2003), its biogeochemical significance in shelf waters remains unclear (McClelland et al., 2012). Riverine nitrate is derived from soil leaching (i.e. moved or dissolved and carried through soil by water) and terrestrial surface run-off (i.e. transported over land in the excess water when soil is infiltrated to full capacity). Soluble reactive phosphorus (SRP) originates from the weathering of crustal minerals (e.g. aluminium orthophosphate, apatite) and silicate from weathering of silicate and aluminosilicate minerals. Along the river path, the specificity of the lithological substrate and permafrost and the terrestrial vegetation are important factors governing the riverine nutrient flux. Glacial or thermokarst lakes also control the nutrient transport from the soil to the river. Around delta lakes, inorganic nutrients can be enhanced via processes involving floodwater percolation among flooded vegetation and soils (e.g. Emmerton et al., 2008). Human activity may also provide nitrate and SRP in the White Sea, which has one of the most industrialized Arctic coastlines. By contrast with nitrogen-limited marine waters, phosphorus is the most limiting element in rivers mostly because its supply to the freshwater system is limited by erosion. Particulate and dissolved organic forms of nitrogen, phosphorus and carbon are also transported to the ocean by rivers. Their fate in the marine environment depends of their lability, of which little is known in Arctic settings.

Previous estimates of riverine nutrients fluxes to the coastal Arctic were either based on annual mean concentrations (Gordeev et al., 1996) or on monthly mean concentrations but derived from a single data set and limited to a portion of the Arctic Basin (Holmes et al., 2000). Recently, an important modelling effort constrained by measurements from the PARTNERS (2003-2007) and Student
Partners (2005-2008) projects during the last decade was made to assess deliveries of riverine dissolved nutrients and their seasonality (Holmes et al., 2011). In the present study, we expanded this effort by compiling extensive historical (1954-2012) data including dissolved nutrients and particulate matter for 9 large Eurasian and North American rivers. The aim was to establish a historical baseline of river fluxes and assess their impact on the biogeochemistry of shelf waters. Particular attention is paid to phosphorus, silica, and particulate organic nitrogen (PON) and carbon (POC), which in recent papers received less attention than dissolved nitrogen (Tank et al., 2012) and carbon (Manizza et al., 2009). We provide the biogeochemical modelling community with time series of monthly averaged concentrations of nitrate, SRP, silicate, and dissolved organic carbon (DOC) and nitrogen (DON) to help constrain riverine boundary conditions in panArctic physical-biological models.

\section{Material and methods}

We compiled riverine nitrate $(n=2436)$, SRP $(n=1618)$, silicate $(n=1683)$, DOC $(n=509)$, DON $(n=380)$, POC $(n=160)$ and PON $(n=160)$ data for 9 large Arctic rivers: the Yenisey (Kara Sea; at Igarka $\left(67.4^{\circ} \mathrm{N}, 86.5^{\circ} \mathrm{E}\right)$ and Dudinka $\left(69.2^{\circ} \mathrm{N}, 86.1^{\circ} \mathrm{E}\right)$ ), Lena (Laptev Sea; at Zhigansk $\left(66.8^{\circ} \mathrm{N}, 123.4^{\circ} \mathrm{E}\right)$, Kyusur $\left(70.7^{\circ} \mathrm{N}, 127.4^{\circ} \mathrm{E}\right)$ and Stolb $\left(72.37^{\circ} \mathrm{N}, 126.80^{\circ} \mathrm{E}\right)$ ), Ob (Kara Sea; at Salekhard $\left(66.6^{\circ} \mathrm{N}, 66.6^{\circ} \mathrm{E}\right)$ ), Mackenzie (Beaufort Sea; at Tsiigehtchic $\left.\left(67.46^{\circ} \mathrm{N}, 133.7^{\circ} \mathrm{W}\right)\right)$, Yukon (Bering Sea; at Pilot Station $\left.\left(61.93^{\circ} \mathrm{N}, 162.88^{\circ} \mathrm{W}\right)\right)$, Pechora (Barents Sea; at Oksino $\left(67.6^{\circ} \mathrm{N}, 52.2^{\circ} \mathrm{E}\right)$ ), Northern Dvina (White Sea; at Ust' Pinega $\left(64.1^{\circ} \mathrm{N}, 41.9^{\circ} \mathrm{E}\right)$ and Arkhangelsk $\left(64.3^{\circ} \mathrm{N}, 40.3^{\circ} \mathrm{E}\right)$ ), Kolyma (East Siberian Sea; at Kolymskoye $\left(68.7^{\circ} \mathrm{N}, 158.7^{\circ} \mathrm{E}\right)$ and Cherskii $\left.\left(68.4^{\circ} \mathrm{N}, 161.2^{\circ} \mathrm{E}\right)\right)$ and Indigirka (East Siberian Sea; at Chokurdakh $\left(70.4^{\circ} \mathrm{N}\right.$, $\left.147.6^{\circ} \mathrm{E}\right)$ ). Data were gathered from 8 publications (Reeder et al., 1972; Macdonald et al., 1987; Létolle et al., 1993; Lara et al., 1998; Holmes et al., 2000; Millot et al., 2003; Savenko and Shevchenko, 2005; Finlay et al., 2006) and 5 databases. The latter are from the PARTNERS project (e.g. McClelland et al., 2008) extended as the Arctic Great Rivers Observatory (Arctic-GRO) project (http://arcticgreatrivers. org/data.html), the United Nations GEMS/WATER Programme (http://www.gemswater.org), United States Geological Survey (USGS) Water-Quality Data for the Nation (http://waterdata.usgs.gov/nwis/qw) and the United Federal Service for Observation and Control of Environmental Pollution (OGSNK/GSN) (Holmes et al., 2000). Data span from 1954 to 2012 with most of the measurements starting from the mid-1980s. The data sets used for each river sampling location are given in Table 1 . With respect to data quality, only a total of 2 dubious nitrate measurements (97 and $117 \mathrm{mmol} \mathrm{N} \mathrm{m}^{-3}$ measured in the Yenisey River at Igarka) were removed from the data set considering maximum nitrate 
Table 1. Data sets of nitrate, silicate, SRP, DOC, DON, POC and PON concentration used for each river sampling location. The number of data for each data set is given between brackets.

\begin{tabular}{|c|c|c|c|c|c|c|c|c|}
\hline River & Site & Nitrate & Silicate & SRP & DOC & DON & POC & PON \\
\hline \multirow[t]{2}{*}{ Yenisey } & Igarka & GEMS/WATER (143) & GEMS/WATER (151) & GEMS/WATER (92) & & & & \\
\hline & Dudinka & $\begin{array}{l}\text { OGSNK/GSN (56) } \\
\text { A-GRO (56) } \\
\text { PARTNERS (17) }\end{array}$ & $\begin{array}{l}\text { A-GRO (56) } \\
\text { PARTNERS (17) }\end{array}$ & $\begin{array}{l}\text { OGSNK/GSN (56) } \\
\text { A-GRO (56) }\end{array}$ & $\begin{array}{l}\text { A-GRO (56) } \\
\text { PARTNERS (16) }\end{array}$ & $\begin{array}{l}\text { A-GRO (56) } \\
\text { PARTNERS (17) }\end{array}$ & $\begin{array}{l}\text { PARTNERS (16) } \\
\text { A-GRO (10) }\end{array}$ & $\begin{array}{l}\text { PARTNERS (16) } \\
\text { A-GRO (10) }\end{array}$ \\
\hline \multirow[t]{3}{*}{ Lena } & Zhigansk & $\begin{array}{l}\text { A-GRO (56) } \\
\text { PARTNERS (17) }\end{array}$ & $\begin{array}{l}\text { A-GRO (57) } \\
\text { PARTNERS (17) }\end{array}$ & $\begin{array}{l}\text { A-GRO (57) } \\
\text { PARTNERS (17) }\end{array}$ & $\begin{array}{l}\text { A-GRO (57) } \\
\text { PARTNERS (17) }\end{array}$ & $\begin{array}{l}\text { A-GRO (56) } \\
\text { A-GRO (10) }\end{array}$ & $\begin{array}{l}\text { PARTNERS (17) } \\
\text { A-GRO (10) }\end{array}$ & PARTNERS (17) \\
\hline & Kyusur & $\begin{array}{l}\text { GEMS/WATER (71) } \\
\text { OGSNK/GSN (59) } \\
\text { Publication (1) }\end{array}$ & $\begin{array}{l}\text { GEMS/WATER (70) } \\
\text { Publication (1) }\end{array}$ & $\begin{array}{l}\text { GEMS/WATER (60) } \\
\text { OGSNK/GSN (57) }\end{array}$ & & & & \\
\hline & Stolb & $\begin{array}{l}\text { GEMS/WATER (94) } \\
\text { Publication (1) }\end{array}$ & $\begin{array}{l}\text { GEMS/WATER (114) } \\
\text { Publication (3) }\end{array}$ & $\begin{array}{l}\text { GEMS/WATER (27) } \\
\text { Publication (1) }\end{array}$ & & & & \\
\hline $\mathrm{Ob}$ & Salekhard & $\begin{array}{l}\text { GEMS/WATER (533) } \\
\text { PARTNERS (17) } \\
\text { A-GRO (52) }\end{array}$ & $\begin{array}{l}\text { GEMS/WATER (366) } \\
\text { A-GRO (52) } \\
\text { PARTNERS (17) }\end{array}$ & $\begin{array}{l}\text { OGSNK/GSN (57) } \\
\text { A-GRO (52) }\end{array}$ & $\begin{array}{l}\text { A-GRO (52) } \\
\text { PARTNERS (17) }\end{array}$ & $\begin{array}{l}\text { A-GRO (52) } \\
\text { PARTNERS (16) }\end{array}$ & $\begin{array}{l}\text { PARTNERS (15) } \\
\text { A-GRO (10) }\end{array}$ & $\begin{array}{l}\text { PARTNERS (15) } \\
\text { A-GRO (10) }\end{array}$ \\
\hline Mackenzie & Tsiigehtchic & $\begin{array}{l}\text { A-GRO (57) } \\
\text { PARTNERS (17) } \\
\text { Publication (2) }\end{array}$ & $\begin{array}{l}\text { A-GRO (57) } \\
\text { GEMS/WATER (48) } \\
\text { PARTNERS (17) } \\
\text { Publication (2) }\end{array}$ & $\begin{array}{l}\text { GEMS/WATER ( } 84) \\
\text { A-GRO (57) }\end{array}$ & $\begin{array}{l}\text { A-GRO (57) } \\
\text { PARTNERS (17) } \\
\text { Publication (1) }\end{array}$ & $\begin{array}{l}\text { A-GRO (57) } \\
\text { PARTNERS (17) }\end{array}$ & $\begin{array}{l}\text { PARTNERS (14) } \\
\text { A-GRO (13) }\end{array}$ & $\begin{array}{l}\text { PARTNERS (14) } \\
\text { A-GRO (13) }\end{array}$ \\
\hline Yukon & Pilot Station & $\begin{array}{l}\text { USGS (67) } \\
\text { A-GRO (47) } \\
\text { PARTNERS (3) }\end{array}$ & $\begin{array}{l}\text { USGS (158) } \\
\text { A-GRO (47) } \\
\text { PARTNERS (3) }\end{array}$ & $\begin{array}{l}\text { USGS (54) } \\
\text { A-GRO (47) }\end{array}$ & $\begin{array}{l}\text { USGS (67) } \\
\text { A-GRO (47) } \\
\text { PARTNERS (11) }\end{array}$ & $\begin{array}{l}\text { A-GRO (47) } \\
\text { PARTNERS (15) }\end{array}$ & $\begin{array}{l}\text { PARTNERS (16) } \\
\text { A-GRO (13) }\end{array}$ & $\begin{array}{l}\text { PARTNERS (16) } \\
\text { A-GRO (13) }\end{array}$ \\
\hline Pechora & Oksino & OGSNK/GSN (155) & & OGSNK/GSN (156) & & & & \\
\hline \multirow{2}{*}{$\begin{array}{l}\text { Northern } \\
\text { Dvina }\end{array}$} & Ust' Pinega & GEMS/WATER (481) & GEMS/WATER (400) & GEMS/WATER (337) & & & & \\
\hline & Arkhangelsk & OGSNK/GSN (170) & & OGSNK/GSN (171) & & & & \\
\hline \multirow[t]{2}{*}{ Kolyma } & Kolymskoye & GEMS/WATER (134) & & GEMS/WATER (84) & & & & \\
\hline & Cherskii & $\begin{array}{l}\text { OGSNK/GSN (40) } \\
\text { PARTNERS (17) } \\
\text { A-GRO (13) }\end{array}$ & $\begin{array}{l}\text { PARTNERS (17) } \\
\text { A-GRO (13) }\end{array}$ & $\begin{array}{l}\text { OGSNK/GSN (40) } \\
\text { A-GRO (13) }\end{array}$ & $\begin{array}{l}\text { Publication (64) } \\
\text { PARTNERS (17) } \\
\text { A-GRO (13) }\end{array}$ & $\begin{array}{l}\text { PARTNERS (17) } \\
\text { A-GRO (13) }\end{array}$ & $\begin{array}{l}\text { PARTNERS (16) } \\
\text { A-GRO (10) }\end{array}$ & $\begin{array}{l}\text { PARTNERS (16) } \\
\text { A-GRO (10) }\end{array}$ \\
\hline Indigirka & Chokurdakh & OGSNK/GSN (60) & & OGSNK/GSN (60) & & & & \\
\hline All rivers & & 2436 & 1683 & 1618 & 509 & 380 & 160 & 160 \\
\hline
\end{tabular}

concentrations of ca. $37 \mathrm{mmol} \mathrm{N} \mathrm{m}^{-3}$ in the Yenisey watershed (e.g. Frey et al., 2007). Ammonium concentrations used in this study are restricted to those of the PARTNERS database, because concentrations measured along the Eurasian side are considered dubious as a result of methodological problems (Holmes et al., 2000, 2001). DON concentrations are also derived from the PARTNERS database. DON concentrations were obtained by subtracting nitrate, nitrite and ammonium from the total dissolved nitrogen pool. SRP is the phosphorus content measured as the orthophosphates prior to the hydrolysis of the dissolved organic phosphorus (DOP).

The source nutrient data were log-transformed to reduce skewness and approach a Gaussian frequency distribution. For nutrients, only geometric monthly averages were used in the remainder of this study. They were obtained by back-transforming the arithmetic averages calculated on logtransformed data. Missing monthly concentrations resulting from the lack of data were estimated using a linear interpolation procedure. The monthly averaged nutrient data were multiplied by the monthly integrated river flow rates from the R-ArcticNet database (http://www.r-arcticnet.sr.unh.edu/ v4.0/index.html) to compute the monthly-integrated nutri- ent fluxes. On average, the monthly integrated flow rates lie within ca. 3-4\% (May-October, ca. $82 \%$ of the annual flow) of the mean annual values reported in the modelling study of Holmes et al. (2011). Nutrient fluxes in the polar mixed layer through Bering Strait and the Barents Sea opening were computed using the geometric mean annual concentrations calculated between 0 and $50 \mathrm{~m}$ from the World Ocean Atlas 2005 (National Oceanographic Data Centre, 2006) for SRP, nitrate and silicate. Values of $0.83 \mathrm{~Sv}\left(1 \mathrm{~Sv}=10^{6} \mathrm{~m}^{3} \mathrm{~s}^{-1}\right)$ and of $0.2 \mathrm{~Sv}$ were used as the mean volume transported through Bering Strait (Roach et al., 1995) and the Barents Sea opening (Ingvaldsen et al., 2004), respectively.

\section{Results and discussion}

\subsection{Concentrations and fluxes of riverine nutrients}

The different nutrients show distinct seasonal patterns in concentration, as demonstrated by the monthly data from stations located as far downriver as possible (Figs. 1 and 2). Nitrate and silicate concentrations are generally highest in winter and decrease during the freshet as a result of 

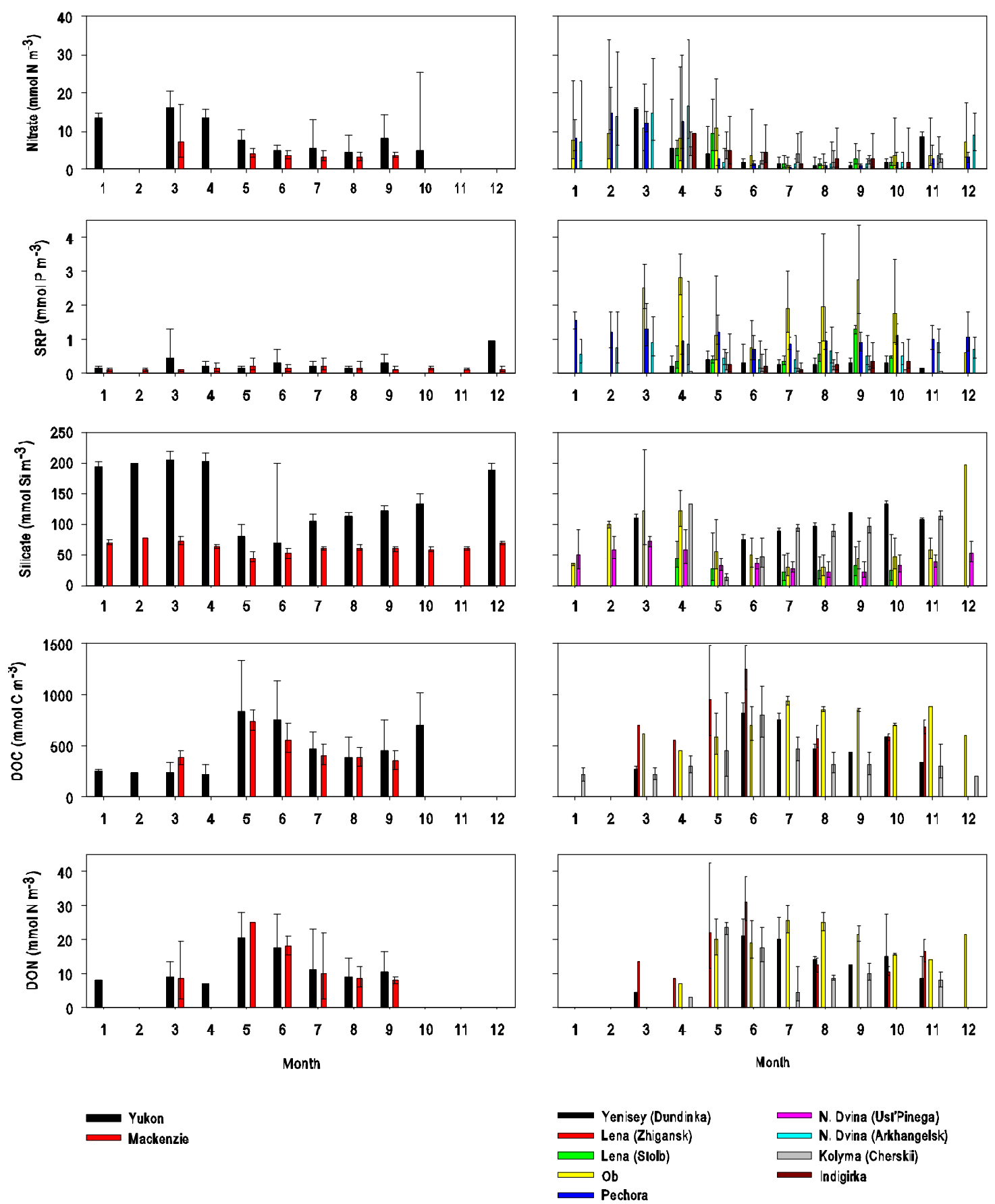

Fig. 1. Monthly-binned concentrations of riverine nitrate, SRP, silicate, DOC and DON for the North American and Eurasian rivers. Bars with no standard deviations indicate single values. Non-filled bars indicate no data available.

dilution (e.g. Sferratore et al., 2008). By contrast, DOC and POC concentrations, and to a lesser extent DON and PON concentrations, peak in May-July during the freshet period and generally decrease thereafter (e.g. Finlay et al., 2006). With regards to SRP, no significant seasonal trend can be drawn from the monthly-binned concentrations (KruskalWallis test, $P>0.05$; R Core Team, 2012; de Mendiburu,
2012) except in the Pechora, Ob and Northern Dvina rivers (Kruskal-Wallis test, $P<0.05$ ), where concentrations drop during the freshet along with those of nitrate and silicate.

Large differences in concentration can be found between rivers. For instance, wintertime silicate concentrations are significantly higher in the Yukon River (ca. $200 \mathrm{mmol} \mathrm{Si} \mathrm{m}^{-3}$ ) than in any other river 

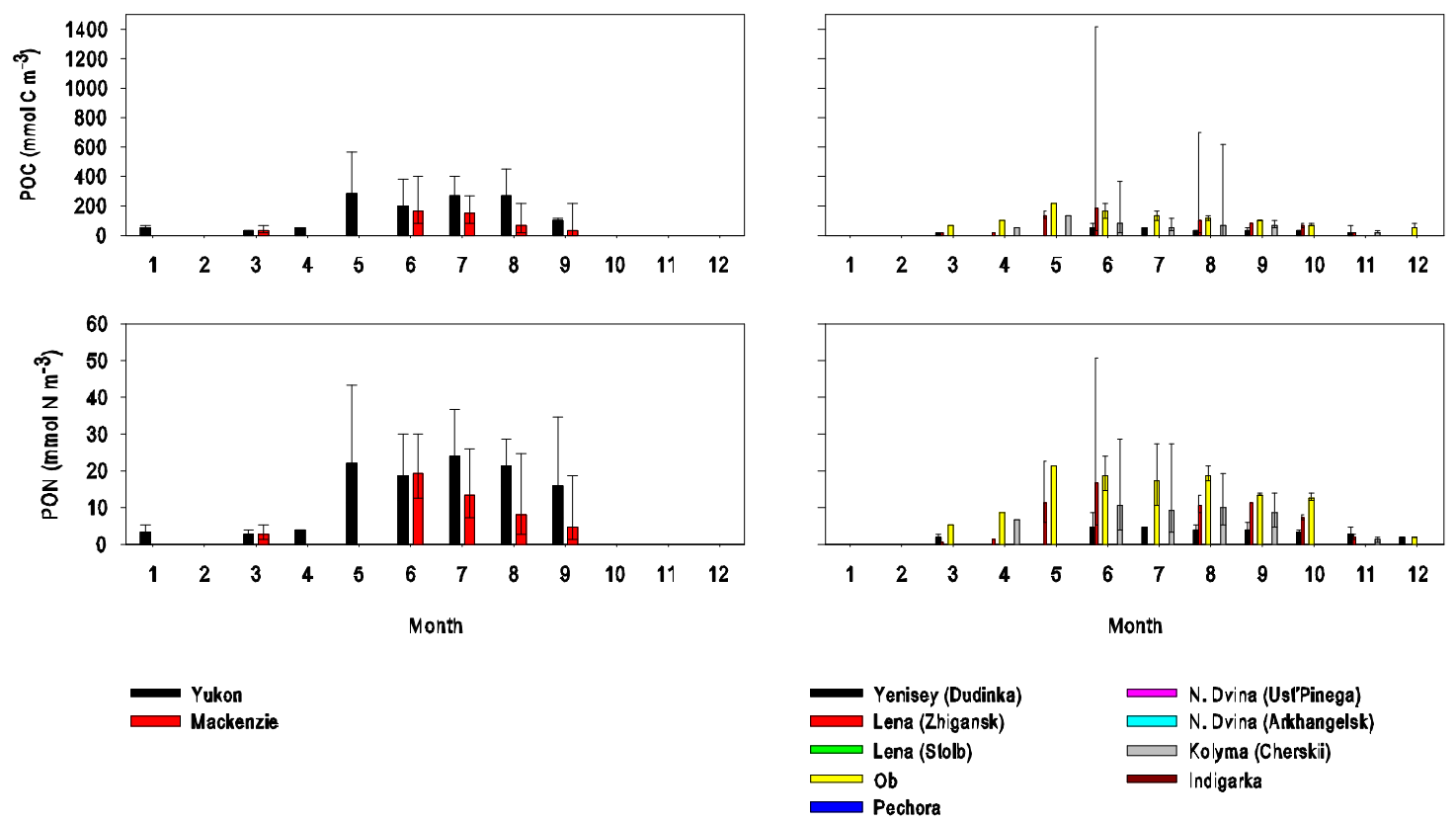

erski)

Pechora

Fig. 2. Monthly-binned concentrations of riverine POC and PON for the North American and Eurasian rivers. Bars with no standard deviations indicate single values. Non-filled bars indicate no data available.

(Kruskal-Wallis test, $P<0.05$ ), and the seasonal variations are large $\left(130 \mathrm{mmol} \mathrm{Si} \mathrm{m}^{-3}\right)$ compared with the Mackenzie River (ca. $25 \mathrm{mmol} \mathrm{Si} \mathrm{m}^{-3}$ ), for example. Greater silicate concentrations in the Yukon River can be explained by the higher dissolved silica yield in the Yukon catchment (Dürr et al., 2011). Regarding SRP, wintertime concentrations are generally significantly higher in the Ob, Pechora and Northern Dvina rivers than in North American rivers (Kruskal-Wallis test, $P<0.05$ ). The Ob River shows the highest SRP concentrations (up to $3 \mathrm{mmol} \mathrm{P} \mathrm{m}^{-3}$ ) prior to and after the seasonal peak discharge in July. Apart from the $\mathrm{Ob}$ River, Eurasian rivers exhibit significant differences in DOC and DON concentrations throughout the year (Kruskal-Wallis test, $P<0.05$ ) but comparable maximum values in spring (ca. $1000 \mathrm{mmol} \mathrm{C} \mathrm{m}^{-3}$ and $20-30 \mathrm{mmol} \mathrm{N} \mathrm{m}^{-3}$ ) (Kruskal-Wallis test, $P<0.05$ ). In August and September, the concentrations of DOC and DON in the $\mathrm{Ob}$ River are significantly higher than those of its North American and Eurasian counterparts (Kruskal-Wallis test, $P<0.05)$. The concentrations of PON and POC are also significantly higher than those of its Eurasian counterparts (Kruskal-Wallis test, $P<0.05$ ), but not significantly different from those of its North American counterparts (Kruskal-Wallis test, $P>0.05$ ).

The standard deviations calculated on concentrations are generally high for all variables except silicate and high values are not restricted to the period of maximum river discharge. The effect of synoptic and interannual variability in discharge (Holmes et al., 2011), which can alter concentrations, in calculating monthly averages likely contributed to the large standard deviations and impacted nutrient flux estimations. Furthermore, the monthly binning procedure in calculating nutrient fluxes prevented any coupled variations in nutrient concentrations and water discharge within month. For constituents that are positively (negatively) correlated with discharge, this leads to underestimation (overestimation). Nevertheless, the mean annual fluxes of riverine nutrients estimated in this study show overall agreement with previously published ones (Table 2). Note that we incorporated measurements made at stations located upstream and downstream of those used in Holmes et al. (2000, 2011). A comparison of flux estimates between stations sampled at different sites along the paths of the Yenisey, Lena, Northern Dvina and Kolyma rivers showed differences for SRP, silicate and, though to a lesser extent, for nitrate. These differences may result, as mentioned above, from uncoupled variations between nutrient concentrations and water discharge in the flux calculation, and/or from differences in data quality amongst data sets (e.g. Holmes et al., 2001). Note that using older data sets did not necessarily translate into higher uncertainty in fluxes. For instance, in the Lena River, the mean annual fluxes of SRP at Zhigansk and Kyusur are similar using either recent (A-GRO, 2009-2010) or older data sets (GEMS/WATER, 1984-1992, and OGSNK/GSN, 19841995) (Table 2). This is, however, not the case for silicate (Table 2). Differences can also be partly explained by discontinuities within the rivers' watersheds (Frey and McClelland, 2009; Gustafsson et al., 2011). In the Lena River, Semiletov et al. (2011) report a substantial variation in Si and total organic carbon concentrations (20\% and $60 \%$, respectively) 

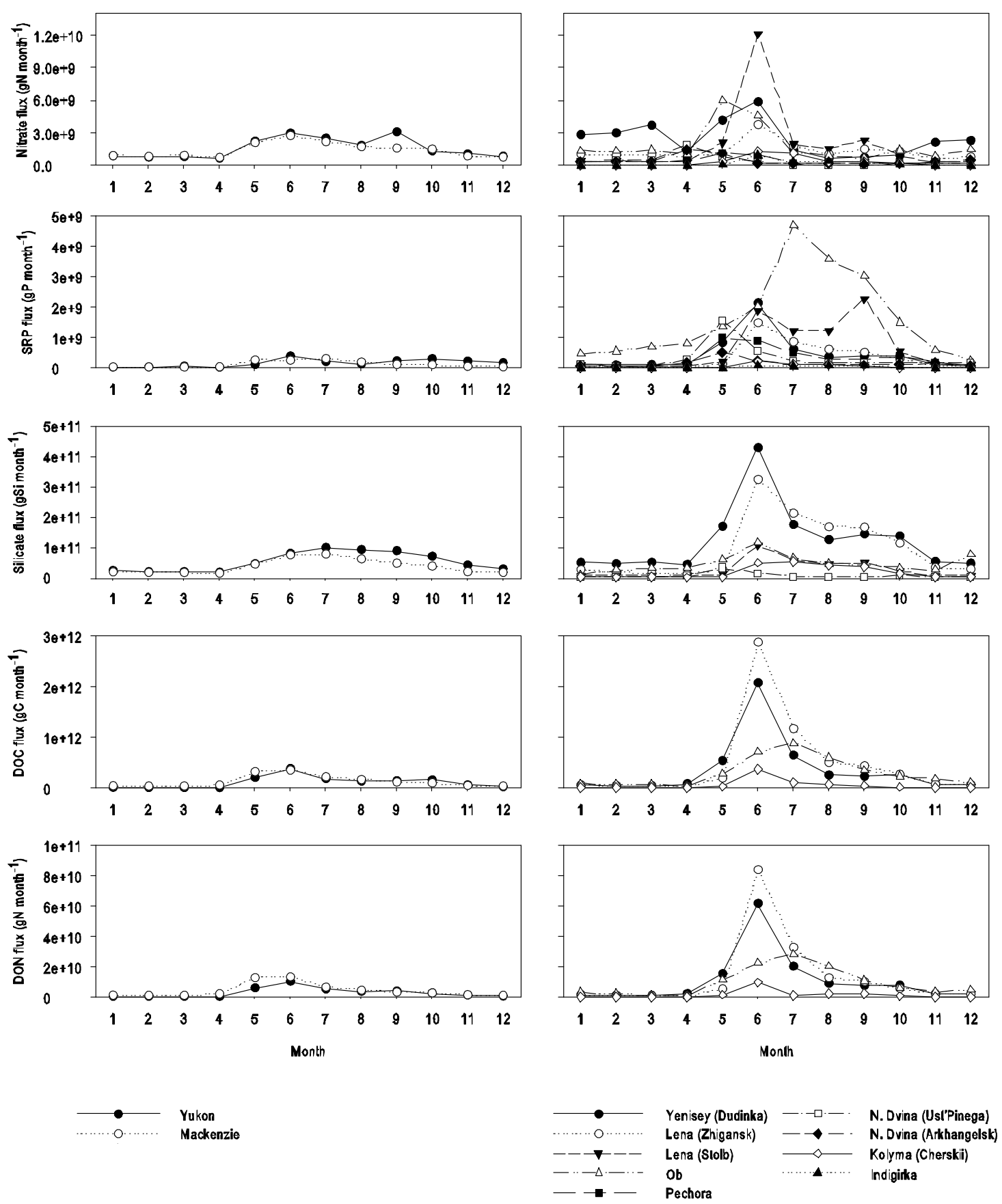

Fig. 3. Monthly flux estimates of riverine nitrate, SRP, silicate, DOC and DON for the North American and Eurasian rivers.

along the $1200 \mathrm{~km}$ stretch separating the Lena delta from Yakutsk. The difficulty to quantitatively distinguish between these possible factors is a limitation in our attempt to quantify precisely the riverine nutrient fluxes. At the seasonal scale, nutrient fluxes are highest during the freshet season (May to July) and generally peak in June (Figs. 3 and 4). They decrease in summer and, in some cases, show a second peak in September-November (Yenisey, Ob, Lena and Yukon rivers). This second peak is not linked to an intensification of freshwater discharge but to an increase in nutrient concentration in the rivers, which possibly results from changes in the watershed (e.g. enhanced permafrost melting, decomposition and/or changes in basin hydrology). The Yenisey, Lena and $\mathrm{Ob}$ rivers show the highest nutrient fluxes as well as the highest annual freshwater discharge and amplitude of seasonal variations, especially during the spring to summer transition.

Relative to the contribution of Bering Strait, the riverine flux of DIN and SRP into the polar mixed layer (PML) is 
Table 2. Annual discharge of freshwater, dissolved inorganic nutrients (nitrate, silicate and SRP), and dissolved and particulate organic carbon (DOC and POC, respectively) and nitrogen (DON and PON, respectively) for 9 rivers entering the Arctic Ocean. Flux estimates calculated from the discharge and nutrients measured at the same river sampling location are in bold. n.d. indicates no data available.

\begin{tabular}{|c|c|c|c|c|c|c|c|c|c|}
\hline & & Discharge & Nitrate & Silicate & SRP & DOC & DON & POC & PON \\
\hline & & $\mathrm{km}^{3} \mathrm{yr}^{-1}$ & $10^{9} \mathrm{~g} \mathrm{~N}$ & $10^{9} \mathrm{~g} \mathrm{Si}$ & $10^{9} \mathrm{~g} \mathrm{P}$ & $10^{9} \mathrm{~g} \mathrm{C}$ & $10^{9} \mathrm{~g} \mathrm{~N}$ & $10^{9} \mathrm{~g} \mathrm{C}$ & $10^{9} \mathrm{~g} \mathrm{~N}$ \\
\hline \multirow[t]{7}{*}{ Yenisey } & Data $^{1 \mathrm{a}}$ & 580 & 20.4 & 843 & 14.3 & n.d. & n.d. & n.d. & n.d. \\
\hline & Data $^{1 b}$ & 580 & 29 & 1480 & 5.4 & 4419 & 132 & 232 & 32 \\
\hline & Gordeev et al. (1996) & 620 & 8.7 & 1857 & 5.8 & n.d. & n.d. & n.d. & n.d. \\
\hline & Gordeev and Kravchishina (2009) & 620 & n.d. & n.d. & n.d. & 4860 & n.d. & 170 & n.d. \\
\hline & Holmes et al. (2000) & 577 & 18.4 & n.d. & 6.2 & n.d. & n.d. & n.d. & n.d. \\
\hline & Dittmar and Kattner (2003) & $562-577$ & n.d & $200-1223$ & n.d & $4100-4900$ & 82 & 170 & 17 \\
\hline & Holmes et al. (2011) & 636 & 49 & 1740 & n.d. & 4645 & 111 & n.d. & n.d. \\
\hline \multirow[t]{7}{*}{ Lena } & $\operatorname{Data}^{2 a}$ & 529 & 15.6 & 1160 & 4.2 & 5785 & 158 & 825 & 94 \\
\hline & Data $^{2 b}$ & 529 & 17.7 & 340 & 4.8 & n.d. & n.d. & n.d. & n.d. \\
\hline & Gordeev et al. (1996) & 525 & 22 & 1029 & 4.9 & n.d. & 243 & n.d. & n.d. \\
\hline & Gordeev and Kravchishina (2009) & 523 & n.d. & n.d. & n.d. & 3600 & n.d. & 1200 & n.d. \\
\hline & Holmes et al. (2000) & 532 & 19.5 & n.d. & 3.5 & n.d. & n.d. & n.d. & n.d. \\
\hline & Dittmar and Kattner (2003) & 524-533 & n.d & $890-1640$ & n.d & $3400-4700$ & $80-245$ & 470 & 54 \\
\hline & Holmes et al. (2011) & 581 & 24 & 1347 & n.d. & 5681 & 135 & n.d. & n.d. \\
\hline \multirow[t]{6}{*}{$\mathrm{Ob}$} & Data $^{3}$ & 596 & 22 & 573 & 19.6 & 3631 & 114 & 585 & 85 \\
\hline & Gordeev et al. (1996) & 429 & 9.4 & 1929 & 18.2 & n.d. & n.d. & n.d. & n.d. \\
\hline & Gordeev and Kravchishina (2009) & 404 & n.d. & n.d. & n.d. & 3680 & n.d. & 360 & n.d. \\
\hline & Holmes et al. (2000) & 404 & 34.8 & n.d. & 23.5 & n.d. & n.d. & n.d. & n.d. \\
\hline & Dittmar and Kattner (2003) & 404-419 & n.d & 311 & n.d & $3100-3200$ & 66 & $310-600$ & $28-54$ \\
\hline & Holmes et al. (2011) & 427 & 57 & 1453 & n.d. & 4119 & 110 & n.d. & n.d. \\
\hline \multirow[t]{4}{*}{ Mackenzie } & Data $^{4}$ & 285 & 16.8 & 464 & 1.5 & 1575 & 50.8 & 317 & 41 \\
\hline & Gordeev et al. (1996) & 249 & 12.5 & 467 & 1.5 & n.d. & n.d. & n.d. & n.d. \\
\hline & Dittmar and Kattner (2003) & $249-333$ & n.d & 470 & n.d & 1300 & 27 & $1800-2100$ & $160-190$ \\
\hline & Holmes et al. (2011) & 298 & 24 & 554 & n.d. & 1377 & 31 & n.d. & n.d. \\
\hline \multirow[t]{2}{*}{ Yukon } & Data $^{5}$ & 204 & 19 & 644 & 1.9 & 1369 & 35.9 & 439 & 50 \\
\hline & Holmes et al. (2011) & 208 & 24 & 694 & n.d. & 1472 & 47 & n.d. & n.d. \\
\hline \multirow[t]{5}{*}{ Pechora } & Data $^{6}$ & 137 & 4.7 & n.d. & 4.0 & n.d. & n.d. & n.d. & n.d. \\
\hline & Gordeev et al. (1996) & 131 & 9.1 & 400 & 1.62 & n.d. & n.d. & n.d. & n.d. \\
\hline & Gordeev and Kravchishina (2009) & 131 & n.d & n.d & n.d & 1666 & n.d. & 40 & n.d. \\
\hline & Dittmar and Kattner (2003) & 135 & n.d & n.d & n.d & 2100 & 44 & n.d. & n.d. \\
\hline & Holmes et al. (2000) & 135 & 7.1 & n.d. & 4.2 & n.d. & n.d. & n.d. & n.d. \\
\hline \multirow[t]{6}{*}{ Northern Dvina } & Data $^{7 \mathrm{a}}$ & 105 & 5.1 & 105 & 3.8 & n.d. & n.d. & n.d. & n.d. \\
\hline & $\operatorname{Data}^{7 b}$ & 105 & 5.1 & n.d. & 1.8 & n.d. & n.d. & n.d. & n.d. \\
\hline & Gordeev et al. (1996) & 110 & 9.2 & 388 & 2 & n.d. & n.d. & n.d. & n.d. \\
\hline & Gordeev and Kravchishina (2009) & 110 & n.d. & n.d. & n.d. & 1280 & n.d. & 28 & n.d. \\
\hline & Dittmar and Kattner (2003) & 106 & n.d. & n.d. & n.d. & 1700 & 35 & n.d. & n.d. \\
\hline & Holmes et al. (2000) & 105 & 6.7 & n.d. & 2 & n.d. & n.d. & n.d. & n.d. \\
\hline \multirow[t]{7}{*}{ Kolyma } & Data $^{8 a}$ & 103 & 3.7 & n.d. & 2.0 & n.d. & n.d. & n.d. & n.d. \\
\hline & Data $^{8 b}$ & 103 & 4.0 & 212 & 0.6 & 651 & 17.3 & 81 & 13 \\
\hline & Gordeev et al. (1996) & 132 & 3.7 & 248 & 1.22 & n.d. & 52.8 & n.d. & n.d. \\
\hline & Gordeev and Kravchishina (2009) & 122 & n.d. & n.d. & n.d. & 740 & n.d. & 380 & n.d. \\
\hline & Holmes et al. (2000) & 70 & 2.5 & n.d. & 0.76 & n.d. & n.d. & n.d. & n.d. \\
\hline & Dittmar and Kattner (2003) & 71-98 & n.d. & n.d. & n.d. & $460-700$ & 16 & 310 & 34 \\
\hline & Holmes et al. (2011) & 111 & 5 & 276 & n.d. & 818 & 17 & n.d. & n.d. \\
\hline \multirow[t]{4}{*}{ Indigirka } & Data $^{9}$ & 50 & 2.0 & n.d. & 0.35 & n.d. & n.d. & n.d. & n.d. \\
\hline & Dittmar and Kattner (2003) & 50 & n.d. & 0.7 & n.d. & $240-400$ & 8.4 & 170 & 24 \\
\hline & Holmes et al. (2000) & 50 & 2.3 & n.d. & 0.35 & n.d. & n.d. & n.d. & n.d. \\
\hline & Gordeev et al. (1996) & 61 & 1.7 & 80 & 0.4 & n.d. & 24.4 & n.d. & n.d. \\
\hline
\end{tabular}

1a discharge at Igarka, DIN/DOC/DON at Igarka; ${ }^{1 \mathrm{~b}}$ discharge at Igarka, DIN/DOC/DON at Dudinka (ca. $250 \mathrm{~km}$ downstream Igarka)

${ }^{2 a}$ discharge at Kyusur, DIN/DOC/DON at Zhigansk; ${ }^{2 b}$ discharge at Kyusur, DIN/DOC/DON at Kyusur (ca. $400 \mathrm{~km}$ downstream Zhigansk); ${ }^{2 \mathrm{c}}$ discharge at Stolb, DIN/DOC/DON near Stolb (delta ca. $520 \mathrm{~km}$ downstream Zhigansk)

3 discharge at Salekhard, DIN/DOC/DON at Salekhard

${ }^{4}$ discharge at Red Arctic, DIN/DOC/DON at Tsiigehtchic

5 discharge at Pilot Station, DIN/DOC/DON at Pilot Station

${ }^{6}$ discharge at Oksino, DIN/DOC/DON at Oksino

7a discharge at Ust' Pinega, DIN/DOC/DON at Ust' Pinega; ${ }^{7 b}$ discharge at Ust' Pinega, DIN/DOC/DON at Arkhangelsk (ca. 60 km downstream Ust' Pinega)

8 a discharge at Kolymskoye, DIN/DOC/DON at Kolymskoye; ${ }^{8 b}$ discharge at Kolymskoye, DIN/DOC/DON at Cherskii (ca. 120 km downstream Kolymskoye)

${ }^{9}$ discharge at Vorontsovo, DIN/DOC/DON at Chokurdakh (ca. $100 \mathrm{~km}$ downstream Vorontsovo) 
minor at the AO scale (Fig. 5). The combined nutrient flux from the 8 rivers (the Yukon was not accounted for as it pours out in the Bering Shelf) is in fact similar to that of the Barents Sea, except for silicate. Rivers account for only ca. $2 \%$ and $4 \%$ of the total horizontal input of allochthonous nitrate and SRP in the surface layer, respectively, whereas their contribution for silicate reaches ca. $11 \%$. As such, rivers and Bering Strait strikingly differ in their potential relative contribution to primary production $(\mathrm{PP})$.

\subsection{Contribution of riverine nutrients to shelf water biogeochemistry}

SRP, nitrate and silicate are key nutrients needed by diatoms to grow and form blooms. Diatom blooms are responsible for new (i.e. nitrate-based) $\mathrm{PP}\left(\mathrm{PP}_{\text {new }}\right)$ and for a majority of this newly produced organic matter to the deep ocean. To assess the contribution of riverine nutrients to $\mathrm{PP}_{\text {new }}$ in the $\mathrm{AO}$, we used nutrient fluxes estimated as far as possible downstream at stations where discharge and nutrient measurements coincided (Table 2). Note, however, that these locations are hundreds of kilometres upstream from the estuaries. As such, the nutrient fluxes do not account for potential removal and enrichment processes occurring in the intervening transition zone (see Emmerton et al., 2008, and the discussion in Tanks et al., 2011). The Lena River, for which fluxes are based on measurements from the delta itself, is an exception. We converted the fluxes of phosphorus, nitrogen and silica into carbon equivalents $\left(\mathrm{PP}_{\text {new }}\right)$ using a molar $\mathrm{C}: \mathrm{N}: \mathrm{P}: \mathrm{Si}$ consumption ratio of 112:14:1:26 (Tremblay et al., 2008). The resulting "potential" $\mathrm{PP}_{\text {new }}$ reflects how much each nutrient and each advective source, when considered separately, would contribute to $\mathrm{AO}$ new primary production if all were converted into organic carbon through phytoplankton growth $\left(\mathrm{PP}_{\text {new }}\right)$. However, since the elemental ratios in source waters depart from the algal requirements observed during blooms, the lowest of the N-, P- or Si-based estimate of carbon consumption is taken as an upper bound on overall $\mathrm{PP}_{\text {new }}$. In other words, the first nutrient to be used up limits $\mathrm{PP}_{\text {new }}$ in Liebig's sense and the other nutrients remain in excess. Utilization of these "leftovers" can occur where the source waters mix with waters in which other nutrients are in excess. We compare our river-related $\mathrm{PP}_{\text {new }}$ estimates with $\mathrm{PP}_{\text {new }}$ values derived from total primary production rates and $\mathrm{f}$ ratios obtained from field measurements and reported in Sakshaug (2004) for the whole AO and its ancillary shelf seas.

The N:P molar flux ratio varies between seasons and rivers (Fig. 6). During the AO productive season (May to September), the $\mathrm{N}: \mathrm{P}$ molar flux ratio in the Yenisey, $\mathrm{Ob}$, Pechora and Northern Dvina rivers is always below the $\mathrm{N}: \mathrm{P}=14: 1$ molar consumption ratio in shelf waters (Simpson et al., 2008), but it can lie above the latter in the Lena, Kolyma, Indigirka, Yukon and Mackenzie rivers. N : P molar flux ratios below the $\mathrm{N}: \mathrm{P}=14: 1$ molar consumption ratio result from SRP or nitrate fluxes respectively higher and lower relative to those from their North American counterparts (Fig. 3), where nitrate exceeds SRP. In estuaries like in the Mackenzie, SRP is removed in the river and no dissolved inorganic phosphate is supplied to marine waters (Macdonald and Yu, 2006). Hence, other sources of phosphorus are needed for phytoplankton to consume the riverine nitrate such as dissolved organic phosphorus and the admixture of Pacific-derived waters enriched in SRP and silicate relative to nitrate (Yamamoto-Kawai et al., 2006). In late winter prior to the bloom period, SRP is present in excess relative to nitrate in the high $\mathrm{AO}(\mathrm{N}: \mathrm{P}: \mathrm{Si}=4.2: 1: 13$; from Canadian Arctic Shelf Exchange Study and Circumpolar Flaw Lead data) and in the Pacific waters flowing in through Bering Strait $(\mathrm{N}: \mathrm{P}: \mathrm{Si}=5.5: 1: 16$; from the World Ocean Atlas 2005, National Oceanographic Data Centre, 2006). Integrated over January to March, the molar fluxes of nitrate and SRP entering the AO are respectively $81 \times 10^{9} \mathrm{~mol} \mathrm{~N}$ and $15 \times 10^{9} \mathrm{~mol} \mathrm{P}$ through the Bering Strait and $1.4 \times 10^{9} \mathrm{molN}$ and $0.1 \times 10^{9} \mathrm{~mol} \mathrm{P}$ from rivers. If all nitrate supplied by the Bering Strait were taken up by phytoplankton according to a molar consumption ratio of $14: 1$, $9.2 \times 10^{9} \mathrm{~mol} \mathrm{P}$ would remain in Pacific-derived waters. The inorganic phosphorus present in Arctic shelf waters is thus sufficient to support the total consumption of inorganic nitrogen brought by rivers as well as Bering Strait.

On an annual basis, the mean riverine nitrate contribution to $\mathrm{AO} \mathrm{PP}_{\text {new }}(<0.83 \%$, Table 3$)$ is small relative to that of the Bering Strait inflow $(<41.2 \%)$, in accord with previous studies (Gordeev et al., 1996; Tank et al., 2011). However, large differences are found across shelf seas (Fig. 7). Rivers contribute the least to $\mathrm{PP}_{\text {new }}$ in the Barents Sea $(0.04 \%)$, the Bering Shelf $(0.11 \%)$ and the East Siberian Sea $(0.4 \%)$, and the most in the White Sea $(6.7 \%)$. The Kara and the Beaufort seas show intermediate values $(2.7-4.7 \%)$. Accounting for the higher range of uncertainty relative to nitrate concentrations makes this contribution to $\mathrm{PP}_{\text {new }}$ rise to $6.7-8.3 \%$ in the White, Kara, Laptev and Beaufort seas. However, the 9 most important rivers taken into account in this study only represent a fraction of the total continental freshwater flow into shelf seas. Using total (i.e. river and groundwater) freshwater discharge estimates from literature, and assuming a proportional relationship with the mean nitrate flux given in Table 2, we can provide a coarse estimate of how much $\mathrm{PP}_{\text {new }}$ might be supported in shelf seas if all continental inputs of fresh water were accounted for. The total discharge (river + groundwater) is estimated to be $1630 \mathrm{~km}^{3} \mathrm{yr}^{-1}, 802 \mathrm{~km}^{3} \mathrm{yr}^{-1}$, and $267 \mathrm{~km}^{3} \mathrm{yr}^{-1}$ in the Kara, Laptev and East Siberian seas, respectively (Gordeev et al., 1999). This is respectively $38 \%, 60 \%$ and $57 \%$ more than the freshwater discharge by the $\mathrm{Ob}$ and Yenisey rivers, the Lena River, and the Kolyma and Indigirka rivers. In the Beaufort Sea, the Colville River, the second most important river after the Mackenzie River $\left(285 \mathrm{~km}^{3} \mathrm{yr}^{-1}\right)$, has a discharge of ca. $15 \mathrm{~km}^{3} \mathrm{yr}^{-1}$ (source: USGS). Accounting for the total freshwater discharge in shelf seas, the mean riverine nitrate 

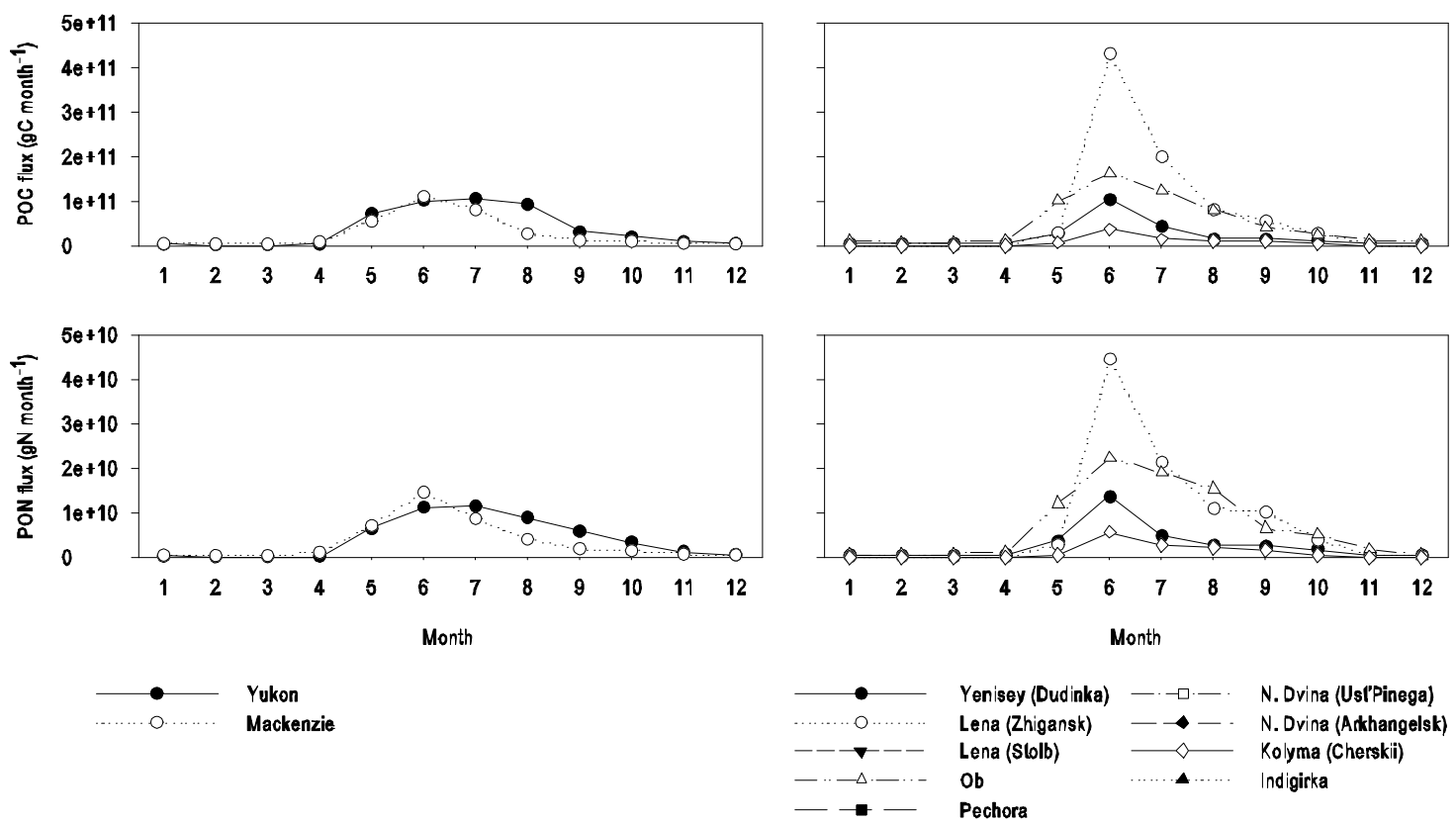

Fig. 4. Monthly flux estimates of riverine POC and PON for the North American and Eurasian rivers.

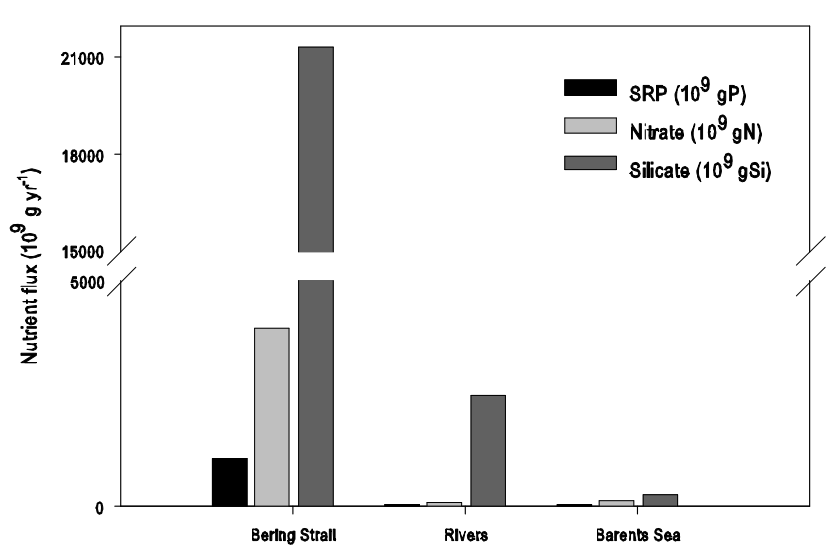

Fig. 5. Annual lateral influx of $\operatorname{SRP}\left(10^{9} \mathrm{~g} \mathrm{P}\right)$, nitrate $\left(10^{9} \mathrm{~g} \mathrm{~N}\right)$ and silicate $\left(10^{9} \mathrm{~g} \mathrm{Si}\right)$ from Bering Strait, 8 circum-Arctic rivers (see text for details) and the Barents Sea.

contribution to $\mathrm{PP}_{\text {new }}$ would rise to $3.8 \%$ (Kara Sea), $5.4 \%$ (Laptev Sea), $0.8 \%$ (East Siberian Sea) and 5.3\% (Beaufort Sea) but would still remain relatively low. Nevertheless, it could be much larger at a local scale. Based on ocean colour data, $\mathrm{PP}_{\text {new }}$ close to the mouth of the Mackenzie River would reach $0.24 \mathrm{Tg} \mathrm{C} \mathrm{yr}^{-1}$ (S. Bélanger, personal communication, 2013). Here, riverine nitrate would meet, on average, $37 \%$ of phytoplankton nitrogen requirements. Note, however, that this contribution to $\mathrm{PP}_{\text {new }}$ is probably less than estimated here since potential biological uptake in the estuarine transition zone (e.g. Emmerton et al., 2008) is not included in the calculation.
The Si : N molar flux ratio departs by one to two orders of magnitude from the molar $\mathrm{Si}: \mathrm{N}$ ratio (1.8) of phytoplankton consumption estimated for the Mackenzie Shelf (Tremblay et al., 2008) and Franklin Bay (Simpson et al., 2008) (Fig. 6). Using a $\mathrm{Si}: \mathrm{N}$ ratio of 1.8 , we assessed how much riverine silicate would be removed by phytoplankton if the entire riverine nitrate pool were used for $\mathrm{PP}_{\text {new }}$ (Fig. 8). For the whole AO, $14.3 \%$ of the riverine silicate would be removed. This percentage is lower in the East Siberian Sea, the Beaufort Sea, Bering Shelf and Kara Sea $(9.7 \%, 8.7 \%$, $9.6 \%$ and $11.4 \%$, respectively) and higher in the Laptev and White seas ( $24.5 \%$ and $17.5 \%$, respectively). This explains why silicate behaves quasi-conservatively when riverine and oceanic waters mix in the coastal zone (Simpson et al., 2008, for the Beaufort Sea; Létolle et al., 1993, for the Laptev Sea). With respect to riverine SRP and using a molar $\mathrm{N}: \mathrm{P}$ consumption ratio of $14: 1,28.9 \%$ of riverine SRP would be removed by phytoplankton across the whole $\mathrm{AO}$ if riverine nitrate were fully consumed. The fraction of riverine SRP used by phytoplankton generally increases from the western Eurasian Basin $(18.6 \%, 21.2 \%$ and $19.8 \%$ in the Barents, White and Kara seas, respectively) towards its eastern counterpart (46\% and $38.4 \%$ in the Laptev and Eastern Siberian seas, respectively) (Fig. 8). By contrast, on the North American side, riverine SRP does not fulfil phytoplankton requirements, and 1.6-fold and 1.8-fold more SRP, likely of oceanic origin, are required to allow riverine nitrate to be fully consumed in the Bering Shelf and Beaufort Sea, respectively. Note that these estimates ignore other processes (e.g. biological uptake, transfer of SRP to the sediment via chemical reactions with iron), which may influence concentrations 

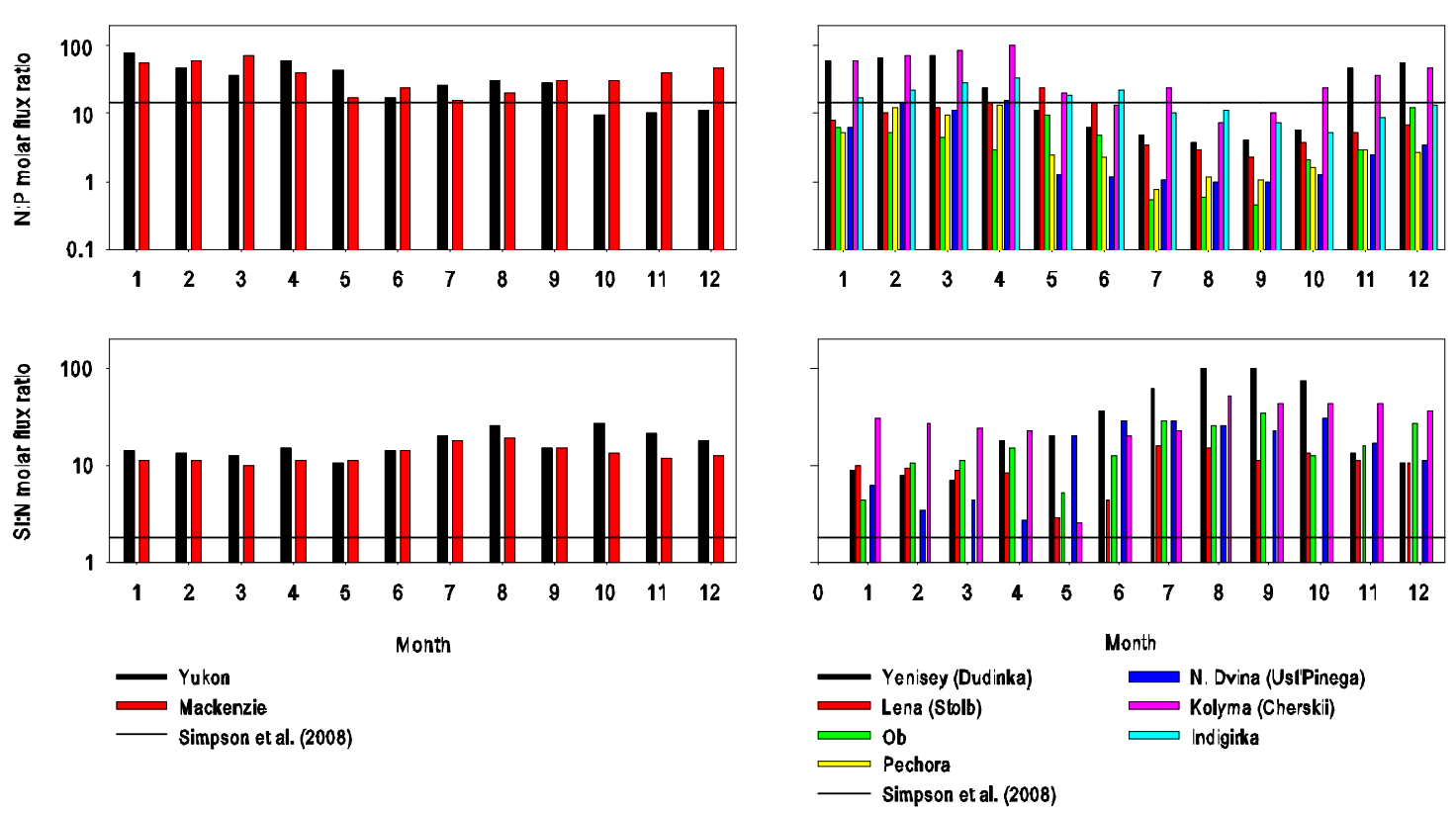

Fig. 6. $\mathrm{N}: \mathrm{P}$ (top panels) and $\mathrm{Si}: \mathrm{N}$ (bottom panels) molar flux ratios computed from monthly flux estimates for the North American and Eurasian rivers.

Table 3. Annual primary production (total $(\mathrm{PP})$ and new $\left(\mathrm{PP}_{\text {new }}\right)$ ), riverine nitrate flux, and contribution of riverine nitrate to new primary production for the high Arctic Ocean and its river-influenced shelf seas. In the last three columns, the average (between brackets) is given along with the average \pm standard deviation.

\begin{tabular}{|c|c|c|c|c|c|c|}
\hline & $\mathrm{PP}(\operatorname{Tg} \mathrm{C})^{*}$ & f-ratio* & $\mathrm{PP}_{\text {new }}(\operatorname{Tg} \mathrm{C})^{*}$ & $\begin{array}{r}\text { Riverine nitrate flux } \\
\left(10^{9} \mathrm{~g} \mathrm{~N}\right)\end{array}$ & $\begin{array}{r}\text { Riverine nitrate flux } \\
\text { in carbon equivalent } \\
(\mathrm{TgC})\end{array}$ & $\begin{array}{r}\text { Riverine nitrate } \mathrm{PP}_{\text {new }} \\
\text { contribution to } \\
(\%)\end{array}$ \\
\hline High Arctic Ocean & $>329$ & 0.2 & $>65.8$ & $213.7-50.8(97.7)$ & $0.29-1.2(0.55)$ & $<0.44-1.8(0.83)$ \\
\hline Barents Sea & 136 & 0.5 & 68 & $9.6-2.5(4.7)$ & $0.01-0.05(0.03)$ & $0.01-0.07(0.04)$ \\
\hline White Sea & 2 & 0.24 & 0.48 & $6.4-2.8(5.1)$ & $0.02-0.04(0.03)$ & $4.2-8.3(6.7)$ \\
\hline Kara Sea & 37 & 0.24 & 8.9 & $112.8-19.9(42.4)$ & $0.11-0.64(0.24)$ & $1.2-7.2(2.7)$ \\
\hline Laptev Sea & 16 & 0.25 & 4 & $47.3-11.7(23)$ & $0.07-0.27(0.13)$ & $1.7-6.7(3.2)$ \\
\hline East Siberian Sea & 30 & 0.25 & 7.5 & $11.2-2.65(5.7)$ & $0.01-0.06(0.03)$ & $0.13-0.8(0.4)$ \\
\hline Bering Shelf & $>300$ & 0.32 & 96 & $37.1-12.3(19)$ & $0.07-0.21(0.11)$ & $0.07-0.22(0.11)$ \\
\hline Beaufort Sea & 8 & 0.24 & 1.9 & $26.4-11.3(16.8)$ & $0.06-0.15(0.09)$ & $3.1-7.9(4.7)$ \\
\hline
\end{tabular}

* From Sakshaug (2004).

along the river-coastal ocean transition zone (Macdonald and $\mathrm{Yu}, 2006)$. Nevertheless, our result is consistent with the high SRP removal reported in the estuarine transition zone (Emmerton et al., 2008) of the Mackenzie River in the Beaufort Sea.

So far our analysis ignored the seasonality of riverine fluxes with respect to primary production. The general picture in our data is that the riverine inorganic flux peaks during the phytoplankton bloom period occurring in May-June in Arctic shelf waters. The bloom accounts for ca. $55 \%$ of annual PP (Pabi et al., 2008) and is mostly sustained by nitrate (f-ratio ca. 0.7; e.g. Le Fouest et al., 2011). In summer when phytoplankton face nitrogen or silica limitation (Walsh and McRoy, 1986; Reigstad et al., 2002; Simpson et al., 2008), PP represents ca. $45 \%$ of annual PP (Pabi et al., 2008) and it is mostly regenerated (f-ratio ca. 0.2 ; e.g. Le Fouest et al., 2011, 2012). Here we assessed the effect of seasonality for the Mackenzie Shelf, where the inflowing Mackenzie River shows one of the highest annual discharge and riverine nitrate contribution to $\mathrm{PP}_{\text {new }}$ (Tables 2 and 3). In this analysis, the contribution of riverine nitrate to $\mathrm{PP}_{\text {new }}$ is only $0.92 \%(0.028 \mathrm{Tg} \mathrm{C})$ during the bloom (total of $3.1 \mathrm{Tg} \mathrm{C})$ but rises to $5.5 \%(0.04 \mathrm{TgC})$ in July-October (total of $0.72 \mathrm{TgC}$ ). The corresponding proportions of riverine silicate needed to fully consume riverine nitrate would be $14.5 \%\left(0.634 \times 10^{9} \mathrm{~mol} \mathrm{Si}\right)$ during the bloom, decreasing to $9.6 \%\left(0.905 \times 10^{9} \mathrm{~mol} \mathrm{Si}\right)$ afterwards. SRP inputs from the Mackenzie River are not sufficient for phytoplankton to 


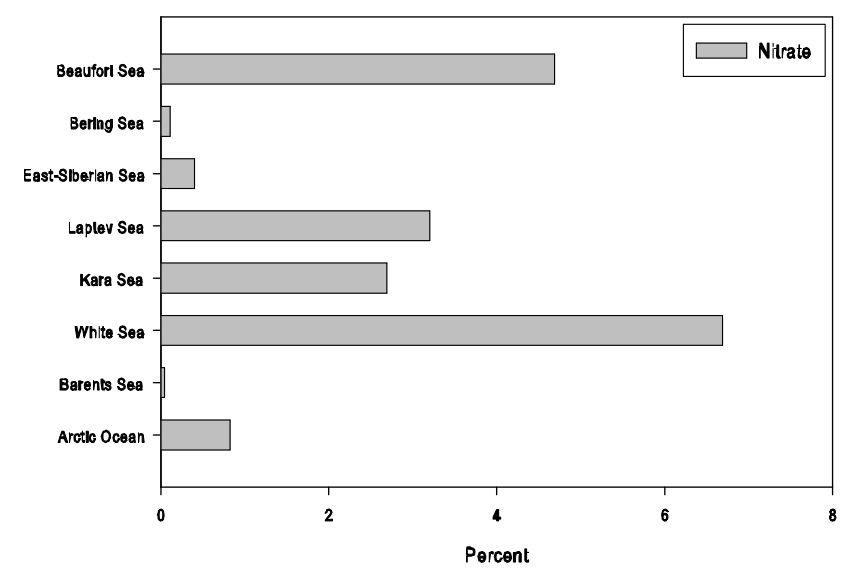

Fig. 7. Contribution of riverine nitrate to new primary production.

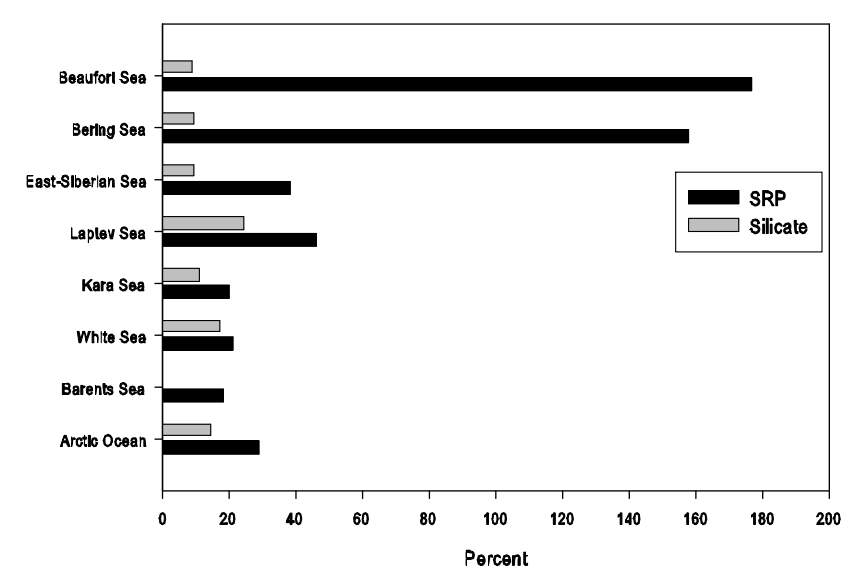

Fig. 8. Fraction of riverine SRP and silicate consumed by phytoplankton in case all riverine nitrate is taken up. Note there were no silicate data for the Pechora River (Barents Sea).

fully take up riverine nitrate. More SRP, likely of oceanic origin, would be required in a larger quantity in JulyOctober $\left(56 \%, 0.013 \times 10^{9} \mathrm{~mol} \mathrm{P}\right)$ than in May-June $(48 \%$, $\left.0.008 \times 10^{9} \mathrm{molP}\right)$. While riverine nitrate potentially contributes more to summer $\mathrm{PP}_{\text {new }}$, the effect must be confined to surface waters due to the strong seasonal stratification (e.g. Li et al., 2009) and isolated from the productive deepchlorophyll maximum responsible for most of summer PP. In this respect, riverine nutrient contributions would be limited to the spring bloom period. A possible mismatch between river floods and shelf blooms (e.g. Kahru et al., 2010) might not affect shelf blooms' intensity owing to the small contribution of terrigenous nutrients.

The summer season is characterized by the highest riverine inputs of dissolved and particulate organic matter (Figs. 3 and 4). In the Ob, Yenisey, Lena, Kolyma and Mackenzie rivers, the mean DOC: POC mass flux ratio lies in the range of 2.8-24.2 between July and October indicating the predominant contribution of DOC versus POC to the organic carbon flux. Conversely, the lower DON : PON mass flux ratio (0.5-4.3) suggests a higher contribution of PON than DON to the organic nitrogen flux. The potential contribution of riverine PON as a significant source of inorganic nitrogen available for phytoplankton growth is, however, limited. The POC: PON molar ratio averaged for July-August for the Ob, Yenisey, Lena, Kolyma and Mackenzie rivers is ca. 9.1, which is higher than the bacterial $\mathrm{C}: \mathrm{N}$ molar ratio (5-7; Anderson and Williams, 1998; Fukuda et al., 1998). Higher POC: PON molar ratios would promote nitrogen limitation of bacteria attached on riverine particles. As a consequence, the nitrogen resulting from riverine PON degradation would rather be consumed by bacteria than by oceanic phytoplankton. Measurements made during the Malina project in summer 2009 in the Beaufort Sea showed that PON could also be photo-degraded into ammonium under the action of the ultraviolet radiation (photoammonification process). Nevertheless, the ammonium hereby photo-produced (ca. $0.002 \mathrm{mmol} \mathrm{N} \mathrm{m}^{-2} \mathrm{~d}^{-1}$ in August; Xie et al., 2012) in the upper $10 \mathrm{~m}$ is negligible with respect to phytoplankton nitrogen demand for PP $\left(>0.1 \mathrm{mmol} \mathrm{N} \mathrm{m}^{-2} \mathrm{~d}^{-1}\right.$ from data of the summer 2009 Malina cruise).

Riverine DON is another substantial source of nitrogen for AO shelf waters (Table 2; see also Holmes et al. 2011). When summing the total riverine fluxes for the Yenisey, Lena, Ob, Mackenzie and Kolyma rivers, the input of DON $\left(33.7 \times 10^{9} \mathrm{~mol} \mathrm{~N} \mathrm{yr}^{-1}\right)$ is ca. 5-fold higher than the corresponding input of riverine nitrate $\left(6.8 \times 10^{9} \mathrm{~mol} \mathrm{~N} \mathrm{yr}^{-1}\right)$. But the relative contribution of DON varies amongst rivers. For instance, the DON flux is 7-fold higher than the flux of nitrate in the Laptev Sea but only 3-fold higher in the Beaufort Sea. The labile fraction of DON is reported to vary from 30 to $40 \%$ in river water (Dittmar et al., 2001; Stepanauskas et al., 2002) to less than $10 \%$ in marine water (Jørgensen et al., 1999; Dittmar et al., 2001). Labile terrigenous DON is actively degraded by marine bacteria (Jørgensen et al., 1999), whereas the refractory pool is either exported to the deep ocean (Dittmar, 2004) or photoammonified and subsequently used by bacteria and phytoplankton (Vähätalo et al., 2011; Le Fouest et al., 2012). Xie et al. (2012; this issue) estimated that ca. $16 \%$ of the total refractory DON in surface waters of the Beaufort Sea was potentially photoammonified between June and August. From the data, ca. $70 \%$ of the combined supply of DON (i.e. $23.4 \times 10^{9} \mathrm{~mol} \mathrm{~N}$ ) from the $\mathrm{Ob}$, Yenisey, Lena, Kolyma and Mackenzie rivers takes place between June and August. Applying this rate to this flux, rivers could indirectly supply $3.9 \times 10^{9} \mathrm{~mol} \mathrm{~N}$ in the form of photochemically produced ammonium, which is fairly comparable to the dissolved inorganic nitrogen that could be produced through microbial degradation of riverine DON (e.g. Letscher et al., 2013). This photochemically produced ammonium exceeds the riverine nitrate flux in summer for the same 5 rivers (ca. $2.8 \times 10^{9} \mathrm{~mol} \mathrm{~N}$ for the June-August period from the monthly flux estimates). For comparison, the June-August riverine ammonium flux summed up for the same 5 rivers 
is only $0.6 \times 10^{9} \mathrm{~mol} \mathrm{~N}$. Photoammonification of refractory riverine DON is potentially a greater source of nitrogen for phytoplankton production than the direct combined supply of nitrate and ammonium by rivers. In the Beaufort Sea, the photochemical production of ammonium from refractory DON would support directly (through phytoplankton uptake) and indirectly (through food web remineralization) $60 \%$ of the total pelagic primary production within the top $10 \mathrm{~m}$ of the water column (Le Fouest et al., 2012).

If all the ammonium photo-produced in summer $\left(3.9 \times 10^{9} \mathrm{molN}\right)$ were to be consumed by phytoplankton in shelf waters, the remaining stock of dissolved inorganic phosphorus would be $8.92 \times 10^{9} \mathrm{molP}$. Even with a projected $50 \%$ increase of riverine DON and nitrate in response to global warming (Frey et al., 2007; McClelland et al., 2007), there would still be sufficient SRP $\left(8.05 \times 10^{9} \mathrm{~mol} P\right)$ in shelf waters to sustain the consumption of nitrogen derived from this pool. The sum of the ammonium photo-produced in summer $\left(3.9 \times 10^{9} \mathrm{molN}\right)$ and the annual riverine influx of ammonium $\left(3.5 \times 10^{9} \mathrm{~mol} \mathrm{~N}\right)$ and nitrate $\left(6.8 \times 10^{9} \mathrm{~mol} \mathrm{~N}\right)$ gives an estimated DIN input of $14.2 \times 10^{9} \mathrm{~mol} \mathrm{~N}$ in coastal waters. Assuming no change in the input of SRP and nitrate from Bering Strait or SRP from rivers, a 9-fold increase of riverine DIN supply would be necessary to enable phytoplankton to consume all the SRP present in shelf waters and induce a shift from a nitrogen-limited PP regime to a phosphorus-limited PP regime. These results support the hypothesis of Tremblay and Gagnon (2009) that primary production is nitrogen-limited in the AO and is likely to remain that way in the face of rapid physical changes in the environment.

\section{Concluding remarks}

In this study we compiled historical measurements of dissolved inorganic nutrients (nitrate, SRP and silicate) and dissolved and particulate organic (carbon and nitrogen) matter from the 9 most important rivers in terms of annual discharge. We used these data to compute monthly averaged concentrations (given in the appendix) and annual fluxes.

From these data, several key points can be emphasized:

1. On an annual basis, the regional contribution of riverine nitrate to $\mathrm{AO} \mathrm{PP}_{\text {new }}$ lies between $<1 \%$ and $6.7 \%$. Nevertheless, this contribution is negligible at the panArctic scale $(<0.83 \%)$. This result is in line with previous studies (Gordeev et al., 1996; Tank et al., 2012).

2. Only $14.3 \%$ of the riverine silicate would be removed by phytoplankton at the Arctic scale $(8.7-24.5 \%$ regionally) if all riverine nitrate were consumed.

3. Excluding estuarine removal processes from the calculations, $28.9 \%$ of the riverine SRP would be removed by phytoplankton at the Arctic scale (18.6-46\% regionally) assuming all riverine nitrate was consumed. A total of 1.6-fold and 1.8-fold more SRP from sources other than riverine are required in the Bering Shelf and Beaufort Sea, respectively.

4. On a seasonal basis, the removal of riverine nitrate, silicate and SRP would be the highest in spring and not in summer when AO shelf waters are nitrogen-limited.

5. The AO will likely remain nitrogen-limited even when considering projected increases in the supply of riverine dissolved inorganic and organic nitrogen. A 9-fold increase of riverine DIN supply would be necessary to induce a shift from a nitrogen-limited PP regime to a phosphorus-limited PP regime.

Setting biogeochemical conditions at river points in panArctic physical-biological models is relevant in a context of increasing river discharge (Shiklomanov and Lammers, 2011) and permafrost melt (Frey and Smith, 2005) resulting from the Arctic warming. River discharge accounts for ca. $38 \%$ of the Arctic freshwater budget (Serreze et al., 2006) and is equivalent to a $0.5 \mathrm{~m}$ layer made of riverine fresh water in the PML (ca. $50 \mathrm{~m}$ in average). This fresh water spreads onto the continental plateau, which makes up $53 \%$ of the total surface area of the AO and ensures ca. $80 \%$ of total AO PP (Sakshaug, 2004). In addition, there is some evidence of an increase in riverine nitrate concentration per unit of discharge in the western Arctic (McClelland et al., 2007), and future projections suggest that riverine nutrient inputs will increase substantially by the end of this century. In West Siberia, predicted warming has been linked to a probable increase of riverine total dissolved nitrogen and DON by $30-50 \%$ and $32-53 \%$, respectively (Frey and al., 2007). Nevertheless, more data relative to Arctic rivers DON and DOC lability and trophic pathways (e.g. balance between autotrophic and heterotrophic processes) are needed to accurately assess their effect on shelf biogeochemistry (e.g. McClelland et al., 2012). Dissolved silica mobilization into the North American Arctic river system is also projected to increase between $35 \%$ and $70 \%$ (Moosdorf et al., 2010), but it might impact new primary production in North Atlantic waters rather than the Arctic waters. This analysis underscores the need to better contrast oceanic nutrient supply processes (i.e. mixing, upwellings and mesoscale activity) with the composition and fate of changing riverine nutrient deliveries in future scenarios of plankton community structure, function and production in the coastal AO. 


\section{Appendix A}

Table A1. Monthly-binned riverine concentrations of nitrate $\left(\mathrm{mmol} \mathrm{N} \mathrm{m}^{-3}\right)$. Linearly interpolated values are shown in italic.

\begin{tabular}{lrrrrrrrrrrrr}
\hline & Jan & Feb & Mar & Apr & May & Jun & Jul & Aug & Sep & Oct & Nov & Dec \\
\hline Northern Dvina $^{\mathrm{a}}$ & 7.8 & 17.1 & 16.4 & 21.5 & 1.6 & 1.2 & 1.0 & 0.9 & 1.0 & 1.0 & 2.2 & 4.7 \\
Northern Dvina $^{\mathrm{b}}$ & 7.4 & 14.1 & 14.6 & 16.6 & 2.0 & 0.8 & 1.3 & 1.6 & 1.3 & 1.7 & 3.6 & 8.8 \\
Pechora $_{\text {Yenisey }}^{\mathrm{c}}$ & 8.0 & 14.8 & 12.3 & 12.8 & 2.9 & 1.6 & 0.7 & 1.1 & 1.0 & 1.7 & 2.9 & 3.0 \\
Yenisey $^{\mathrm{d}}$ & 0.8 & 0.7 & 18.2 & 12.1 & 6.5 & 1.1 & 1.0 & 1.0 & 1.1 & 1.1 & 1 & 0.9 \\
Ob & 12.1 & 14 & 15.9 & 5.6 & 4.2 & 2.0 & 1.4 & 1.0 & 1.2 & 1.8 & 8.3 & 10.2 \\
Lena $^{\mathrm{e}}$ & 7.8 & 9.4 & 10.7 & 7.9 & 10.7 & 3.8 & 1.0 & 1.1 & 1.3 & 3.6 & 3.5 & 7.4 \\
Lena $^{\mathrm{f}}$ & 9.8 & 12.4 & 15.1 & 16.0 & 4.3 & 1.4 & 1.2 & 1.0 & 1.7 & 2.4 & 4.5 & 7.2 \\
Lena $^{\mathrm{g}}$ & 4.2 & 5.1 & 6.1 & 7.0 & 8.0 & 3.1 & 1.1 & 1.7 & 1.2 & 1.3 & 2.3 & 3.2 \\
Indigirka $_{\text {Kolyma }}^{\mathrm{h}}$ & 3.6 & 4.1 & 4.7 & 5.3 & 9.5 & & 1.3 & 1.6 & 2.9 & 1.8 & 2.4 & 3.0 \\
Kolyma $^{\mathrm{i}}$ & 5.6 & 6.8 & 8.1 & 9.3 & 4.8 & 4.5 & 1.4 & 2.7 & 2.7 & 1.9 & 3.1 & 4.4 \\
Yukon $_{\text {Mackenzie }}^{7.4}$ & 9.0 & 10.7 & 6.5 & 4.7 & 2.8 & 1.5 & 2.1 & 2.0 & 2.4 & 4.1 & 5.7 \\
& 4.0 & 4.6 & 5.3 & 6.0 & 5.0 & 2.4 & 4.1 & 1.7 & 2.2 & 2.4 & 2.6 & 3.3 \\
& 13.4 & 14.8 & 16.1 & 13.7 & 7.7 & 5.0 & 5.3 & 4.4 & 8.3 & 5.0 & 7.8 & 10.6 \\
\end{tabular}

${ }^{\text {a }}$ Ust' Pinega; ${ }^{\mathrm{b}}$ Arkhangelsk; ${ }^{\mathrm{c}}$ Igarka; ${ }^{\mathrm{d}}$ Dudinka; ${ }^{\mathrm{e}}$ Zhigansk; ${ }^{\mathrm{f}}$ Kyusur; ${ }^{\mathrm{g}}$ Stolb; ${ }^{\mathrm{h}}$ Kolymskoye; ${ }^{\mathrm{i}}$ Cherskii

Table A2. Monthly-binned riverine concentrations of SRP $\left(\mathrm{mmol} \mathrm{P} \mathrm{m}^{-3}\right)$. Linearly interpolated values are shown in italic.

\begin{tabular}{lcccccccccccc}
\hline & Jan & Feb & Mar & Apr & May & Jun & Jul & Aug & Sep & Oct & Nov & Dec \\
\hline Northern Dvina $^{\mathrm{a}}$ & 1.21 & 1.24 & 1.52 & 1.36 & 1.36 & 1.01 & 0.90 & 0.89 & 0.98 & 0.84 & 0.92 & 1.33 \\
Northern Dvina $^{\mathrm{b}}$ & 0.58 & 0.74 & 0.90 & 0.86 & 0.44 & 0.42 & 0.42 & 0.65 & 0.53 & 0.50 & 0.89 & 0.70 \\
Pechora $_{\text {Yenisey }}^{\mathrm{c}}$ & 1.54 & 1.19 & 1.29 & 0.98 & 1.20 & 0.69 & 0.88 & 0.95 & 0.91 & 1.12 & 1.02 & 1.09 \\
Yenisey $^{\mathrm{d}}$ & 0.60 & 0.58 & 1.10 & 1.69 & 0.88 & 0.86 & 0.60 & 0.80 & 0.62 & 0.67 & 0.65 & 0.63 \\
Ob & 0.19 & 0.21 & 0.22 & 0.23 & 0.38 & 0.33 & 0.28 & 0.26 & 0.30 & 0.33 & 0.17 & 0.18 \\
Lena $^{\mathrm{e}}$ & 1.23 & 1.86 & 2.49 & 2.83 & 1.09 & 0.78 & 1.92 & 1.98 & 2.77 & 1.77 & 1.19 & 0.60 \\
Lena $^{\mathrm{f}}$ & 0.24 & 0.24 & 0.24 & 0.23 & 0.23 & 0.25 & 0.26 & 0.27 & 0.26 & 0.26 & 0.25 & 0.25 \\
Lena $^{\mathrm{g}}$ & 0.23 & 0.24 & 0.24 & 0.24 & 0.24 & 0.43 & 0.21 & 0.18 & 0.25 & 0.23 & 0.23 & 0.23 \\
Indigirka $_{\text {Kolyma }}^{\mathrm{h}}$ & 0.44 & 0.42 & 0.40 & 0.38 & 0.39 & 0.38 & 0.37 & 0.56 & 1.30 & 0.49 & 0.47 & 0.45 \\
Kolyma $^{\mathrm{i}}$ & 0.32 & 0.31 & 0.29 & 0.28 & 0.26 & 0.20 & 0.14 & 0.24 & 0.37 & 0.37 & 0.35 & 0.34 \\
Yukon $_{\text {Mackenzie }}$ & 0.21 & 0.18 & 0.16 & 0.14 & 0.35 & 0.95 & 0.33 & 0.58 & 0.49 & 0.27 & 0.25 & 0.23 \\
& 0.07 & 0.06 & 0.06 & 0.06 & 0.24 & 0.18 & 0.17 & 0.23 & 0.22 & 0.10 & 0.07 & 0.07 \\
& 0.17 & 0.32 & 0.46 & 0.22 & 0.18 & 0.30 & 0.20 & 0.14 & 0.29 & 0.52 & 0.74 & 0.97 \\
\end{tabular}

${ }^{\text {a }}$ Ust' Pinega; ${ }^{\text {b }}$ Arkhangelsk; ${ }^{\mathrm{c}}$ Igarka; ${ }^{\mathrm{d}}$ Dudinka; ${ }^{\mathrm{e}}$ Zhigansk; ${ }^{\mathrm{f}}$ Kyusur; ${ }^{\mathrm{g}}$ Stolb; ${ }^{\mathrm{h}}$ Kolymskoye; ${ }^{\mathrm{i}}$ Cherskii

Table A3. Monthly-binned riverine concentrations of silicate $\left(\mathrm{mmol} \mathrm{Si} \mathrm{m}^{-3}\right)$. Linearly interpolated values are shown in italic.

\begin{tabular}{lrrrrrrrrrrrr}
\hline & Jan & Feb & Mar & Apr & May & Jun & Jul & Aug & Sep & Oct & Nov & Dec \\
\hline Northern Dvina $^{\mathrm{a}}$ & 48.3 & 57.9 & 71.4 & 57.8 & 33.0 & 34.5 & 28.3 & 21.6 & 22.5 & 32.0 & 37.8 & 51.5 \\
Yenisey $^{\mathrm{b}}$ & 128.2 & 155.0 & 40.7 & 46.4 & 45.5 & 39.3 & 43.8 & 49.2 & 55.8 & 47.8 & 74.6 & 101.4 \\
Yenisey $^{\mathrm{c}}$ & 109.1 & 110.2 & 111.4 & 98.6 & 85.9 & 73.1 & 87.0 & 97.2 & 118.2 & 132.6 & 106.7 & 107.9 \\
Ob & 34.1 & 98.2 & 121.4 & 121.5 & 54.1 & 40.9 & 29.5 & 28.4 & 43.4 & 45.4 & 57.0 & 45.6 \\
Lena $^{\mathrm{d}}$ & 129.7 & 125.8 & 121.9 & 132.5 & 58.0 & 60.4 & 71.3 & 82.1 & 94.9 & 107.6 & 137.5 & 133.6 \\
Lena $^{\mathrm{e}}$ & 31.5 & 30.6 & 29.6 & 28.7 & 27.7 & 14.4 & 27.4 & 20.3 & 31.3 & 34.4 & 33.4 & 32.5 \\
Lena $^{\mathrm{f}}$ & 34.1 & 37.7 & 41.3 & 44.9 & 27.3 & 23.7 & 20.1 & 23.4 & 31.7 & 23.2 & 26.8 & 30.4 \\
Kolyma $^{\mathrm{g}}$ & 121.9 & 125.8 & 129.8 & 133.7 & 12.7 & 47.0 & 92.4 & 89.1 & 97.3 & 105.7 & 114.0 & 117.9 \\
Yukon $_{\text {Mackenzie }}^{192.4}$ & 200 & 205.3 & 202.6 & 80.6 & 68.6 & 105.7 & 112.2 & 120.7 & 133.0 & 160.9 & 188.7 \\
\hline
\end{tabular}

${ }^{\mathrm{a}}$ Ust' Pinega; ${ }^{\mathrm{b}}$ Igarka; ${ }^{\mathrm{c}}$ Dudinka; ${ }^{\mathrm{d}}$ Zhigansk; ${ }^{\mathrm{e}}$ Kyusur; ${ }^{\mathrm{f}}$ Stolb; ${ }^{\mathrm{g}}$ Cherskii 
Table A4. Monthly-binned riverine concentrations of DON $\left(\mathrm{mmol} \mathrm{N} \mathrm{m}^{-3}\right)$. Linearly interpolated values are shown in italic.

\begin{tabular}{lrrrrrrrrrrrr}
\hline & Jan & Feb & Mar & Apr & May & Jun & Jul & Aug & Sep & Oct & Nov & Dec \\
\hline Yenisey $^{\mathrm{a}}$ & 6.6 & 5.5 & 4.5 & 10.0 & 15.5 & 21.0 & 20.1 & 13.8 & 12.3 & 14.8 & 8.6 & 7.6 \\
Ob & 18.0 & 14.4 & 10.7 & 7.1 & 20.0 & 19.1 & 25.6 & 25.0 & 21.7 & 15.5 & 14.1 & 21.6 \\
Lena $^{\mathrm{b}}$ & 14.9 & 14.1 & 13.3 & 8.7 & 22.0 & 31.2 & 21.8 & 12.4 & 11.5 & 10.6 & 16.5 & 15.7 \\
Kolyma $^{\mathrm{c}}$ & 6.0 & 5.0 & 4.1 & 3.1 & 23.3 & 17.6 & 4.5 & 8.7 & 10.2 & 9.1 & 7.9 & 6.9 \\
Yukon $_{\text {Mackenzie }}$ & 7.9 & 8.4 & 8.9 & 7.1 & 20.6 & 17.6 & 11.1 & 9.1 & 10.6 & 9.9 & 9.3 & 8.6 \\
& 8.2 & 8.2 & 8.3 & 16.6 & 24.9 & 17.9 & 10.1 & 8.7 & 7.9 & 8.0 & 8.0 & 8.1 \\
\hline
\end{tabular}

${ }^{\text {a }}$ Dudinka; ${ }^{\text {b }}$ Zhigansk; ${ }^{\mathrm{c}}$ Cherskii

Table A5. Monthly-binned riverine concentrations of DOC $\left(\mathrm{mmol} \mathrm{C} \mathrm{m}^{-3}\right)$. Linearly interpolated values are shown in italic.

\begin{tabular}{lcccccccccccc}
\hline & Jan & Feb & Mar & Apr & May & Jun & Jul & Aug & Sep & Oct & Nov & Dec \\
\hline Yenisey $^{\mathrm{a}}$ & 300 & 282 & 265 & 452 & 640 & 827 & 753 & 465 & 441 & 583 & 334 & 317 \\
Ob $_{\text {Lena }}^{\mathrm{b}}$ & 609 & 612 & 616 & 458 & 589 & 696 & 942 & 857 & 849 & 708 & 889 & 605 \\
Kolyma $^{\mathrm{c}}$ & 692 & 696 & 700 & 558 & 946 & 1252 & 915 & 577 & 583 & 589 & 684 & 688 \\
Yukon $_{\text {Mackenzie }}$ & 242 & 218 & 223 & 311 & 456 & 797 & 463 & 316 & 312 & 310 & 307 & 196 \\
& 341 & 234 & 219 & 842 & 759 & 464 & 382 & 459 & 710 & 555 & 400 \\
\hline
\end{tabular}

${ }^{\text {a }}$ Dudinka; ${ }^{\mathrm{b}}$ Zhigansk; ${ }^{\mathrm{c}}$ Cherskii

Table A6. Monthly-binned riverine concentrations of PON $\left(\mathrm{mmol} \mathrm{N} \mathrm{m}^{-3}\right)$. Linearly interpolated values are shown in italic.

\begin{tabular}{|c|c|c|c|c|c|c|c|c|c|c|c|c|}
\hline & Jan & Feb & Mar & Apr & May & Jun & Jul & Aug & Sep & Oct & Nov & Dec \\
\hline Yenisey $^{\mathrm{a}}$ & 1.86 & 1.74 & 1.62 & 2.62 & 3.61 & 4.61 & 4.73 & 4.12 & 3.94 & 3.45 & 2.21 & 1.98 \\
\hline $\mathrm{Ob}$ & 2.93 & 3.98 & 5.03 & 8.61 & 21.50 & 18.78 & 17.06 & 18.87 & 13.25 & 12.88 & 7.38 & 1.87 \\
\hline Lena ${ }^{b}$ & 1.46 & 1.15 & 0.70 & 1.34 & 11.39 & 16.55 & 14.23 & 10.64 & 11.47 & 7.25 & 1.85 & 1.56 \\
\hline Kolyma $^{\mathrm{c}}$ & 3.30 & 4.29 & 5.29 & 6.29 & 8.42 & 10.56 & 9.10 & 9.83 & 8.21 & 4.75 & 1.30 & 2.30 \\
\hline Yukon & 3.42 & 2.94 & 2.45 & 3.74 & 22.04 & 18.86 & 24.08 & 21.24 & 15.63 & 12.58 & 9.52 & 6.47 \\
\hline Mackenzie & 3.26 & 2.93 & 2.60 & 8.25 & 13.91 & 19.56 & 13.40 & 7.68 & 4.57 & 4.24 & 3.91 & 3.58 \\
\hline
\end{tabular}

${ }^{\mathrm{a}}$ Dudinka; ${ }^{\mathrm{b}}$ Zhigansk; ${ }^{\mathrm{c}}$ Cherskii

Table A7. Monthly-binned riverine concentrations of POC $\left(\mathrm{mmol} \mathrm{C} \mathrm{m}^{-3}\right)$. Linearly interpolated values are shown in italic.

\begin{tabular}{|c|c|c|c|c|c|c|c|c|c|c|c|c|}
\hline & Jan & Feb & Mar & Apr & May & Jun & Jul & Aug & Sep & Oct & Nov & Dec \\
\hline Yenisey $^{a}$ & 16.7 & 15.6 & 14.4 & 23.2 & 32.0 & 40.8 & 49.1 & 24.3 & 26.3 & 24.1 & 19.1 & 17.9 \\
\hline $\mathrm{Ob}$ & 56.7 & 59.3 & 61.9 & 93.5 & 207.5 & 160.3 & 130.8 & 114.1 & 97.4 & 71.9 & 63.0 & 54.1 \\
\hline Lena $^{b}$ & 13.5 & 10.7 & 6.5 & 13.3 & 135.0 & 187.0 & 155.0 & 90.3 & 72.5 & 58.9 & 16.8 & 14.2 \\
\hline Kolyma $^{\mathrm{c}}$ & 27.7 & 34.3 & 40.9 & 47.5 & 126.7 & 77.6 & 53.9 & 56.5 & 59.7 & 37.1 & 14.5 & 21.1 \\
\hline Yukon & 47.6 & 37.8 & 27.9 & 50.9 & 283.7 & 200.0 & 257.2 & 255.8 & 94.6 & 82.9 & 71.1 & 59.4 \\
\hline Mackenzie & 30.1 & 29.7 & 29.3 & 77.0 & 124.6 & 172.3 & 145.1 & 58.8 & 31.7 & 31.3 & 30.9 & 30.5 \\
\hline
\end{tabular}

a Dudinka; ${ }^{\mathrm{b}}$ Zhigansk; $^{\mathrm{c}}$ Cherskii

Acknowledgements. VLF also acknowledges support from the European Space Agency and the Centre national d'études spatiales (CNES) as part of the Malina project, funded by the Institut national des sciences de l'univers - Centre national de la recherche scientifique (CYBER/LEFE and PICS programmes), the Agence nationale de la recherche and the CNES. MB is supported by the Canada Excellence Research Chair in "Remote sensing of Canada's new Arctic frontier". JET is supported by the National Science and Engineering Research Council of Canada (NSERC) and the ArcticNet Network of Canadian Centres of Excellence. The authors wish to thank J. Finlay, R. M. Holmes, A. V. Savenko and S. Tank for having kindly provided nutrient data.

Edited by: W. Miller 


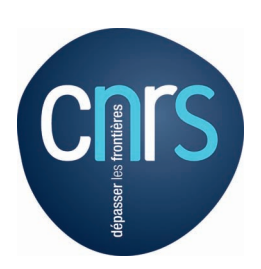

The publication of this article is financed by CNRS-INSU.

\section{References}

Anderson, T. R. and Le B. Williams, P. J.: Modelling the seasonal cycle of dissolved organic carbon at Station E1 in the English Channel, Estuar. Coast. Shelf S., 46, 93-109, 1998.

Arrigo, K. R., van Dijken, G., and Pabi, S.: Impact of a shrinking Arctic ice cover on marine primary production, Geophys. Res. Lett., 35, 10.1029/2008GL035028, 2008.

Bates, N. R. and Mathis, J. T.: The Arctic Ocean marine carbon cycle: evaluation of air-sea $\mathrm{CO}_{2}$ exchanges, ocean acidification impacts and potential feedbacks, Biogeosciences, 6, 2433-2459, doi:10.5194/bg-6-2433-2009, 2009.

de Mendiburu, F.: agricolae: Statistical Procedures for Agricultural Research, R package version 1.1-3, http://CRAN.R-project.org/ package=agricolae, 2012.

Dittmar, T.: Evidence for terrigenous dissolved organic nitrogen in the Arctic deep sea, Limnol. Oceanogr., 49, 148-156, 2004.

Dittmar, T. and Kattner, G.: The biogeochemistry of the river and shelf ecosystem of the Arctic Ocean: A review, Mar. Chem., 83, 103-120, 2003.

Dittmar, T., Fitznar, H. P., and Kattner, G.: Origin and biogeochemical cycling of organic nitrogen in the eastern Arctic Ocean as evident from D- and L-amino acids, Geochim. Cosmochim. Ac., 65, 4103-4114, 2001.

Dürr, H. H., Meybeck, M., Hartmann, J., Laruelle, G. G., and Roubeix, V.: Global spatial distribution of natural riverine silica inputs to the coastal zone, Biogeosciences, 8, 597-620, doi:10.5194/bg-8-597-2011, 2011.

Emmerton, C. A., Lesack, L. F. W., and Vincent, W. F.: Nutrient and organic matter patterns across the Mackenzie River, estuary and shelf during the seasonal recession of sea-ice, J. Marine Syst., 74, 741-755, doi:10.1016/j.jmarsys.2007.10.001, 2008.

English, T. S.: Some biological oceanographic observations in the Central North Polar Sea, Drift Station Alpha, 1957-1958, Arctic Inst. N. Am. Res. Pap. 13, 64 pp., 1961.

Finlay, J., Neff, J., Zimov, S., Davydova, A., and Davydov, S.: Snowmelt dominance of dissolved organic carbon in high-latitude watersheds: Implications for characterization and flux of river DOC, Geophys. Res. Lett., 33, L10401, doi:10.1029/2006GL025754, 2006.

Frey, K. E. and McClelland, J. W.: Impacts of permafrost degradation on arctic river biogeochemistry, Hydrol. Process., 23, 169182, doi:10.1002/hyp.7196, 2009.

Frey, K. E. and Smith, L. C.: Amplified carbon release from vast West Siberian peatlands by 2100 , Geophys. Res. Lett., 32 , L09401, doi:10.1029/2004GL022025, 2005.

Frey, K. E, McClelland, J. W., Holmes, R. M., and Smith, L. C.: Impacts of climate warming and permafrost thaw on the riverine transport of nitrogen and phosphorus to the Kara Sea, J. Geophys. Res.-Biogeo., 112, G04S58, doi:10.1029/2006JG000369, 2007.
Fukuda, R., Ogawa, H., Nagata, T., and Koike, I.: Direct determination of carbon and nitrogen contents of natural bacterial assemblage in marine environments, Appl. Environ. Microbiol., 64, 3352-3358, 1998.

Gordeev, V. V. and Kravchishina, M. D.: River flux of dissolved organic carbon (DOC) and particulate organic carbon (POC) to the Arctic Ocean: what are the consequences of the global changes?, in: Influence of Climate Change on the Changing Arctic and SubArctic Conditions, edited by: Nihoul, J. C. J. and Kostianoy, A. G., Springer Science + Buisiness Media B. V., 145-160, 2009.

Gordeev, V. V., Martin, J. M., Sidorov, I. S., and Sidorova, M. V.: A reassessment of the Eurasian river input of water, sediment, major elements, and nutrients to the Arctic Ocean, Am. J. Sci., 296, 664-691, 1996.

Gustafsson, Ö., van Dongen, B. E., Vonk, J. E., Dudarev, O. V., and Semiletov, I. P.: Widespread release of old carbon across the Siberian Arctic echoed by its large rivers, Biogeosciences, 8, 1737-1743, doi:10.5194/bg-8-1737-2011, 2011.

Hannah, C. G., Dupont, F., and Dunphy, M.: Polynyas and tidal currents in the Canadian Arctic Archipelago, Arctic, 62, 83-95, 2009.

Holmes, R. M., Peterson, B. J., Gordeev, V. V., Zhulidov, A. V., Meybeck, M., Lammers, R. B., and Vörösmarty, C. J.: Flux of nutrients from Russian rivers to the Arctic Ocean: Can we establish a baseline against which to judge future changes?, Water Resour. Res., 36, 2309-2320, 2000.

Holmes, R. M., Peterson, B. J., Zhulidov, A. V., Gordeev, V. V., Makkaveev, P. N., Stunzhas, P. A., Kosmenko, L. S., Köhler, G. H., and Shiklomanov, A. I.: Nutrient chemistry of the $\mathrm{Ob}$ and Yenisey Rivers, Siberia: results from June 2000 expedition and evaluation of long-term data sets, Mar. Chem., 75, 219-227, 2001.

Holmes, R. M., McClelland, J. W., Peterson, B. J., Tank, S. E., Bulygina, E., Eglinton, T. I., Gordeev, V. V., Gurtovaya, T. Y., Raymond, P. A., Repeta, D. J., Staples, R., Stiegl, R. G., Zhulidov, A. V., and Zimov, S. A.: Seasonal and annual fluxes of nutrients and organic matter from large rivers to the Arctic Ocean and surrounding seas, Estuar. Coast, 35, 369-382, doi:10.1007/s12237011-9386-6, 2011.

Ingvaldsen, R. B., Asplin, L., and Loeng, H.: The seasonal cycle in the Atlantic transport to the Barents Sea during the years 1997-2001, Cont. Shelf. Res., 24, 1015-1032, doi:10.1016/j.csr.2004.02.011, 2004.

Jørgensen, N. O. G., Tranvik, L. J., and Berg, G. M.: Occurrence and bacterial cycling of dissolved nitrogen in the Gulf of Riga, the Baltic Sea, Mar. Ecol.-Prog. Ser., 191, 1-18, 1999.

Kahru, M., Brotas, V., Manzano-Sarabia, M., and Mitchell, B. G.: Are phytoplankton blooms occurring earlier in the Arctic?, Glob. Change Biol., 17, 1733-1739, doi:10.1111/j.13652486.2010.02312.x, 2011.

Lara, R. J., Rachold, V., Kattner, G., Hubberten, H. W., Guggenberger, G., Skoog, A., and Thomas, D.: Dissolved organic matter and nutrients in the Lena River, Siberian arctic: Characteristics and distribution, Mar. Chem., 59, 301-309, 1998.

Le Fouest, V., Postlethwaite, C., M. Morales Maqueda, A., Bélanger, S., and Babin, M.: On the role of tides and strong wind events in promoting summer primary production in the Barents Sea, Ocean Sci., 7, 203-217, doi:10.5194/os-7-203-2011, 2011. 
Le Fouest, V., Zakardjian, B., Xie, H., Raimbault, P., Joux, F., and Babin, M.: Plankton ecosystem functioning and nitrogen fluxes in the most oligotrophic waters of the Beaufort Sea, Arctic Ocean: a modeling study, Biogeosciences Discuss., 9, 1475114793, doi:10.5194/bgd-9-14751-2012, 2012.

Létolle, R., Martin, J. M., Thomas, A. J., Gordeev, V. V., Gusarova, S., and Sidorvo, I. S.: ${ }^{18} \mathrm{O}$ abundance and dissolved silicate in the Lena delta and Laptev Sea (Russia), Mar. Chem. 43, 47-64, 1993.

Letscher, R. T., Hansell, D. A., Kadko, D., and Bates, N. R.: Dissolved organic nitrogen dynamics in the Arctic Ocean, Mar. Chem., 148, 1-9, doi:0.1016/j.marchem.2012.10.002, 2013.

Li, W. K. W., McLaughlin, F. A., Lovejoy, C., and Carmack, E. C.: Smallest algae thrive as the Arctic Ocean freshens, Science, 326, p. 539, 2009.

Macdonald, R. W. and Yu, Y.: The Mackenzie Estuary of the Arctic Ocean, in: Water Pollution: Estuaries, edited by: Wangersky, P. J., 5, Springer-Verlag, Heidelberg, 305 pp., 2006.

Macdonald, R. W., Iseki, K., O'Brien, M. C., McLaughlin, F. A., McCullough, D., Macdonald, D. M., Carmack, E. C., Adams, H., Yunker, M., Miskulin, G., and Buckingham, S.: NOGAP B.6; Volume 5: chemical data collected in the Beaufort Sea and Mackenzie river delta, March-July 1987, Can. Data Rep. Hydrogr. Ocean Sci., 60, p. 103, 1987.

Manizza, M., Follows, M. J., Dutkiewicz, S., McClelland, J. W., Menemenlis, D., Hill, C. N., Townsend-Small, A., and Peterson, B. J.: Modeling transport and fate of riverine dissolved organic carbon in the Arctic Ocean, Global Biogeochem. Cy., 23, GB4006, doi:10.1029/2008GB003396, 2009.

McClelland, J. W., Stieglitz, M., Pan, F., Holmes, R. M., and Peterson, B. J.: Recent changes in nitrate and dissolved organic carbon export from the upper Kuparuk River, North Slope, Alaska, J. Geophys. Res., 112, G04S60, doi:10.1029/2006JG000371, 2007.

McClelland, J. W., Holmes, R. M., Peterson, B. J., Amon, R., Brabets, Cooper, T., L., Gibson, J., Gordeev, V. V., Guay, C., Milburn, D., Staples, R., Raymond, P. A., Shiklomanov, I., Striegl, R., Zhulidov, A., Gurtovaya, T., and Zimov, S.: Development of a panarctic Database for River Chemistry, EOS, Transactions American Geophysical Union, 89, 217-218, doi:10.1029/2008EO240001, 2008.

McClelland, J. W., Holmes, R. M., Dunton, K. H., and Macdonald, R. W.: The Arctic Ocean estuary, Estuar. Coast., 35, 353-368, doi:10.1007/s12237-010-9357-3, 2012.

Millot, R., Gaillardet, J., Dupré, B., and Allègre, C. J.: Northern latitude chemical weathering rates; clues from the Mackenzie River basin, Canada, Geoch. Cosmoch. Ac., 67, 1305-1329, 2003.

Moosdorf, N., Hartmann, J., and Lauerwald, R.: Changes in dissolved silica mobilization into river systems draining North America until the period 2081-2100, J. Geochem. Explor., 110, 31-39, doi:10.1016/j.gexplo.2010.09.001, 2010.

Mundy, C. J., Gosselin, M., Ehn, J., Gratton, Y., Rossnagel, A., Barber, D. Martin, G., J., Tremblay, J.-E., Palmer, M., Arrigo, K., Damis, G., Fortier, L., Else, B., and Papakyriakou, T.: Contributions of under-ice primary production to an ice-edge upwelling phytoplankton bloom in the Canadian Beaufort Sea, Geophys. Res. Let., 36, L17601, doi:10.1029/2009GL038837, 2009.

National Oceanographic Data Centre World Ocean Atlas 2005: Documentation accompanying WOA05 DVD (ASCII text and portable document format). Prepared by the Ocean Climate Lab- oratory, National Oceanographic Data Center, Silver Springs, MD 20910, 12 pp, 2006.

Opsahl, S., Benner, R., and Amon, R. M. W.: Major flux of terrigenous dissolved organic matter through the Arctic Ocean, Limnol. Oceanogr., 44, 2017-2023, 1999.

Pabi, S., van Dijken, G. L., and Arrigo, K. R.: Primary production in the Arctic Ocean, 1998-2006, J.Geophys.Res., 113, C08005, doi:10.1029/2007JC004578, 2008.

R Core Team: R: A language and environment for statistical computing, R Foundation for Statistical Computing, Vienna, Austria, ISBN 3-900051-07-0, http://www.R-project.org, 2012.

Reeder, S. W., Hitchon, B., and Levinson, A. A.: Hydrogeochemistry of the surface waters of the Mackenzie River drainage basin, Canada 1. Factors controlling inorganic composition, Geoch. Cosmoch. Ac., 36, 825-865, doi:10.1016/0016-7037(72)90053$1,1972$.

Reigstad, M., Wassmann, P., Wexels Riser, C., Oygarden, S., and Rey, F.: Variation in hydrography, nutrients, and chlorophyll a in the marginal ice-zone and the central Barents Sea, J. Marine Sys., 38, 9-29, 2002.

Roach, A. Aagaard, T., K., Pease, C. H., Salo, S. A., Weingartner, T., Pavlov, V., and Kulakov, M.: Direct measurement of transport and water properties through the Bering Strait, J. Geophys. Res., 100, 18443-18457, 1995.

Sakshaug, E.: Primary and secondary production in the Arctic seas, in: The organic carbon cycle in the Arctic Ocean, edited by: Stein, R. and MacDonald, R. W., Springer-Verlag, Berlin, 57-81, 2004.

Savenko, A. V. and Shevchenko, V. P.: Seasonal variability of the distribution of dissolved forms of biogenic elements and alkalinity in the Northern Dvina mouth, Water Res., 32, 417-421, doi:10.1007/s11268-005-0052-x, 2005.

Semiletov, I. P., Pipko, I. I., Shakhova, N. E., Dudarev, O. V., Pugach, S. P., Charkin, A. N., McRoy, C. P., Kosmach, D., and Gustafsson, Ö.: Carbon transport by the Lena River from its headwaters to the Arctic Ocean, with emphasis on fluvial input of terrestrial particulate organic carbon vs. carbon transport by coastal erosion, Biogeosciences, 8, 2407-2426, doi:10.5194/bg8-2407-2011, 2011.

Serreze, M. C., Barrett, A. P., Slater, A. G., Woodgate, R. A., Aagaard, K., Lammers, R. B., Steele, M., Moritz, R., Meredith, M., and Lee, C. M.: The large-scale freshwater cycle of the Arctic, J. Geophys. Res., 111, C11010, doi:10.1029/2005JC003424, 2006.

Sferratore, A., Billen, G., Garnier, J., Smedberg, E., Humborg, C., and Rahm, L.: Modelling nutrient fluxes from sub-arctic basins: Comparison of pristine vs. dammed rivers, J. Marine Syst., 73, 236-249, 2008.

Shiklomanov, A. and Lammers, R. B.: River discharge (in Arctic Report Card 2011), available at http://www.arctic.noaa.gov/ report11/river_discharge.html, (last access: 1 June, 2012), 2011.

Simpson, K. J., Tremblay, J.-E., Gratton, Y., and Price, N. M.: An annual study of inorganic and organic nitrogen and phosphorus and silicic acid in the southeastern Beaufort Sea, J. Geophys. Res., 113, C07016, doi:10.1029/2007JC004462, 2008.

Stepanauskas, R., Jorgenson N. O. G., Eigaard, O. R., Zvikas A., Tranvik L. J., and Leonardson L.: Summer inputs of riverine nutrients to the Baltic Sea: bioavailability and eutrophication relevance, Ecol. Monogr., 72, 579-597, 2002. 
Tank, S. E., Manizza, M., Holmes, R. M., McClelland, J. W., and Peterson, B. J.: The processing and impact of dissolved riverine nitrogen in the Arctic Ocean, Estuar. Coast., 35, 401-415, doi:10.1007/s12237-011-9417-3, 2012.

Timmermans, M. L., Toole, J., Proshutinsky, A., Krishfield, R., and Plueddemann A.: Eddies in the Canada basin, Arctic Ocean, observed from ice-tethered profilers, Am. Meteorol. Soc., 38, 133145, doi:10.1175/2007JPO3782.1, 2008.

The Arctic-GRO (Arctic Great Rivers Observatory) project, available at: http://arcticgreatrivers.org/data.html, (last access: $1 \mathrm{Au}-$ gust 2012), 2012.

The R-ArcticNet database of panarctic river discharge, available at: http://www.r-arcticnet.sr.unh.edu/v4.0/index.html, (last access: 1 August 2012), 2012.

The United Nations GEMS/WATER Programme, Accessed on the internet at http://www.unep.org/gemswater, (last access: $1 \mathrm{Au}-$ gust 2012), 2012.

The USGS (United States Geological Survey) Water-Quality Data for the Nation, available at: http://waterdata.usgs.gov/nwis/qw, , (last access: 1 August 2012), 2012.

Tremblay, J.-E. and Gagnon, J.: The effects of irradiance and nutrient supply on the productivity of Arctic waters: a perspective on climate change, in: Influence of climate change on the changing Arctic and Subarctic conditions, edited by: Nihoul, J. C. J. and Kostianoy, A. G., NATO Science for Peace and Security SeriesC: Environmental Security, 73-93, 2009.

Tremblay J.-E., Simpson, K., Martin, J. J., Miller, L., Gratton, Y., Barber, D., and Price, N. M.: Vertical stability and the annual dynamics of nutrients and chlorophyll fluorescence in the coastal, southeast Beaufort Sea, J. Geophys. Res.-Oceans, 113, C07S90, 2008 .
Tremblay, J.-E., Bélanger, S., Barber, D. G., Asplin, M., Martin, J., Darnis, G., Fortier, L., Gratton, Y., Link, H., Archambault, P., Sallon, A., Michel, C., Williams, W. G., Philippe, B., and Gosselin, M.: Climate forcing multiplies biological productivity in the coastal Arctic Ocean, Geophys. Res. Lett., 38, L18604, doi:10.1029/2011GL048825, 2011.

Vähätalo, A. V., Aarnos, H., Hoikkala, L., and Lignell, R.: Photochemical transformation of terrestrial dissolved organic matter supports hetero- and autotrophic production in coastal waters, Mar. Ecol.-Prog. Ser., 423, 1-14, doi:10.3354/meps09010, 2011.

Walsh, J. J. and McRoy, C. P.: Ecosystem analysis in the southeastern Bering Sea, Cont. Shelf Res., 5, 259-288, 1986.

Wassmann, P., Slagstad, D., Wexels Riser, C., and Reigstad, M.: Modelling the ecosystem dynamics of the Barents Sea including the marginal ice zone. II. Carbon flux and interannual variability, J. Marine Syst., 59, 1-2, 2006.

Xie, H., Bélanger, S., Song, G., Benner, R., Taalba, A., Blais, M., Lefouest, V., Tremblay, J.-É., and Babin, M.: Photoproduction of ammonium in the Southeastern Beaufort Sea and its biogeochemical implications, Biogeosciences Discuss., 9, 4441-4482, doi:10.5194/bgd-9-4441-2012, 2012.

Yamamot-Kawai, M., Carmack, E. C., and McLaughlin, F. A.: Brief communications: Nitrogen balance and Arctic throughflow, Nature, 443, p. 43, doi:10.1038/443043a, 2006. 